
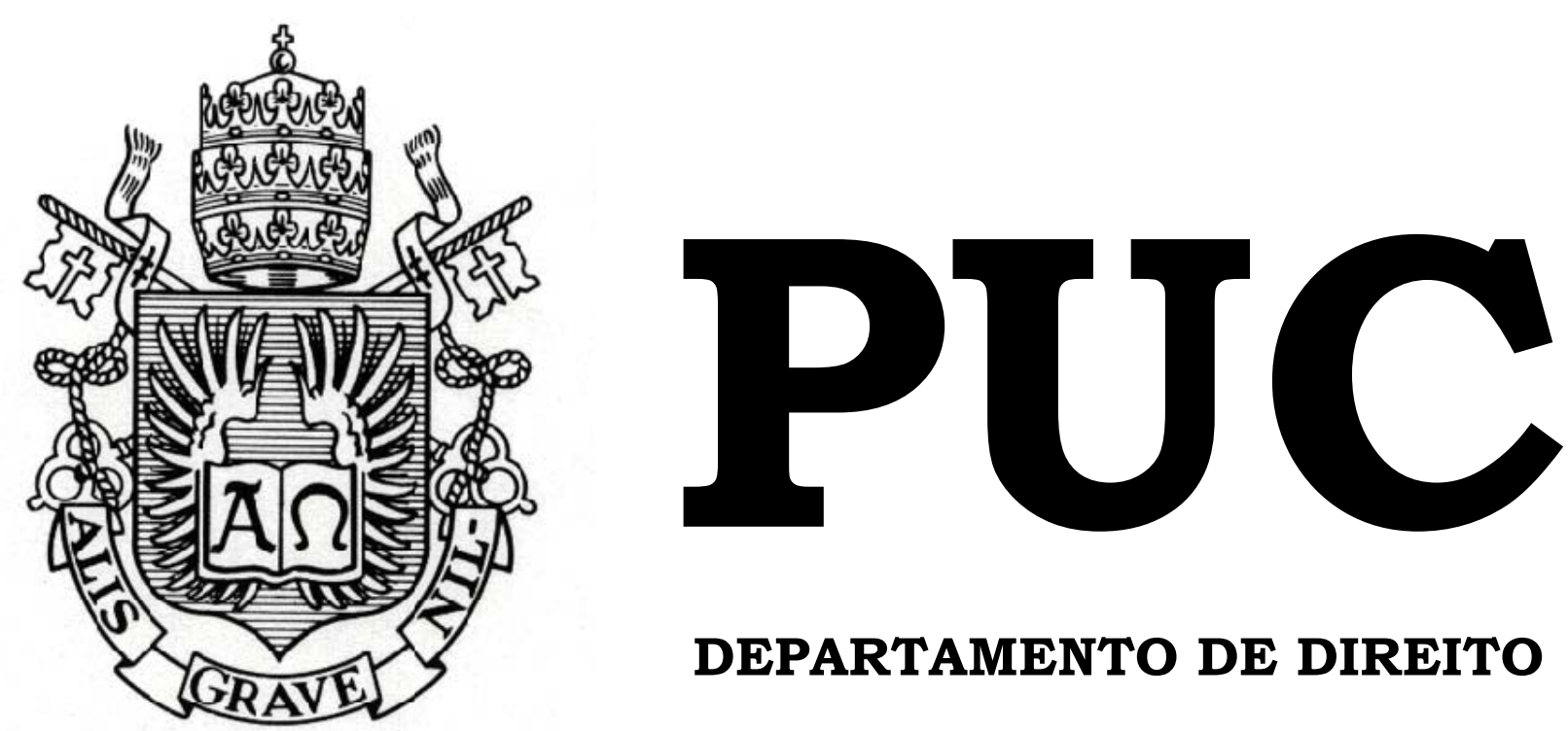

DEPARTAMENTO DE DIREITO

\title{
TRADIÇÕES E PROPRIEDADE DA TERRA EM PROCESSOS DE DEMARCAÇÃO DE TERRAS INDÍGENAS
}

por

FLÁVIA LANAT SILVEIRA

ORIENTADORA: ROSÂNGELA LUNARDELLI CAVALLAZZI

2015.1

PONTIFÍCIA UNIVERSIDADE CATÓLICA DO RIO DE JANEIRO

RUA MARQUÊS DE SÃO VICENTE, 225 - CEP 22453-900

RIO DE JANEIRO - BRASIL 


\title{
TRADIÇÕES E PROPRIEDADE DA TERRA EM PROCESSOS DE DEMARCAÇÃO DE TERRAS INDÍGENAS
}

\author{
por \\ FLÁVIA LANAT SILVEIRA
}

Monografia apresentada ao Departamento de Direito da Pontificia Universidade Católica do Rio de Janeiro (PUC-Rio) para a obtenção do Título de Bacharel em Direito.

Orientadora: Rosângela Lunardelli Cavallazzi 
"(...) porque a terra, para cada um de nós, é muito mais do que um pequeno pedaço de terra negociável. Nós temos uma relação espiritual com a terra de nossos ancestrais. Nós não negociamos direitos territoriais porque a terra, para nós, representa a nossa vida. A terra é mãe e mãe não se vende, não se negocia. Mãe se cuida, mãe se defende, mãe se protege."

(Sônia Guajajara) 


\section{Agradecimentos}

Agradeço a meus pais, Mônica e Alexandre, por todo carinho, amor e dedicação que tiveram comigo ao longo desses anos e por terem permitido que o sonho de cursar Direito fosse possível.

À minha avó, Annita, e ao meu irmão, Henrique, que não sabem, mas contribuíram indiretamente para essa monografia, deixando meus dias mais leves, com brincadeiras e risadas.

Também agradeço a minhas amigas de infância, que estão comigo nessa caminhada e ao meu namorado, Gustavo, que acompanhou o desenvolvimento desse trabalho.

Aos membros da Biblioteca Marechal Rondon, localizada no Museu do Índio, pela atenção que tiveram comigo durante todos os dias que estive lá.

Não poderia deixar de agradecer também a Luiz Henrique Eloy Amado, índio Terena e advogado, que hoje luta pelos direitos de diversas populações indígenas, por ter compartilhado alguns ensinamentos.

E por fim, mas não menos importante, agradeço à minha querida professora e orientadora, Rosangela Cavallazzi, pela transmissão de alguns de seus conhecimentos e principalmente pela atenção que me deu ao longo da elaboração da presente monografia. 


\section{Resumo}

A presente monografia considerando as tradições e os direitos dos índios em relação a terra visa estudar as dimensões legislativa e judiciária especialmente em processos de demarcação das terra indígenas, no contexto da Constituição brasileira de 1988. A pesquisa realizada considerou a situação de vulnerabilidade do povo indígena no Brasil desde a época da colonização portuguesa, agravada nos processos de demarcação de terras com a reduzida eficácia social da norma constitucional, fundada no indigenato, que protege os direitos indígenas. $\mathrm{O}$ estudo privilegia a análise do caso referência Raposa Serra do Sol como método que permite explicitar os conflitos em torno da questão. A análise do caso permitiu observar que apesar da firme legislação protetora dos direitos indígenas, a prática jurídica, inclusive nos tribunais, ao adotarem o requisito do marco temporal, uma nova tradição está sendo “protegida”, uma tradição inventada.

\section{Palavras-chave:}

Terra indígena. Tradição. Vulnerabilidade. Regime jurídico de terras. Demarcação de terras. 


\section{Sumário}

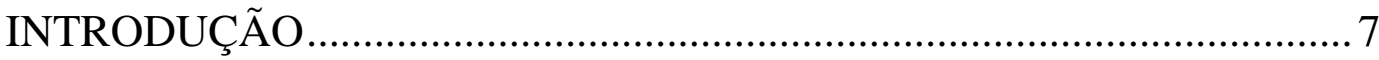

\section{CAPÍTULO 1. CONTEXTUALIZAÇÃO DA QUESTÃO INDÍGENA}

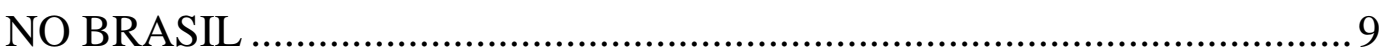

1.1. Tradição e identidade cultural indígena ................................................ 9

1.1.1. O significado da terra para o índio ............................................................... 11

1.2. A chegada dos colonizadores portugueses ........................................... 16

1.3. O novo sentido de terra dado pelos portugueses ...................................21

1.4. Das primeiras legislações sobre a terra indígena......................................22

\section{CAPÍTULO 2. AS TERRAS INDÍGENAS E A CONSTITUIÇÃO}

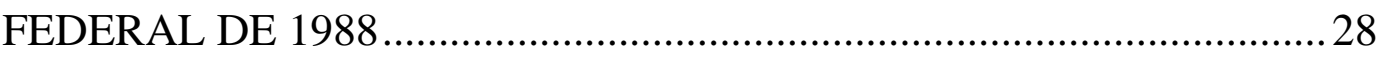

2.1. A terra indígena segundo a Constituição Federal de 1988 ..................... 28

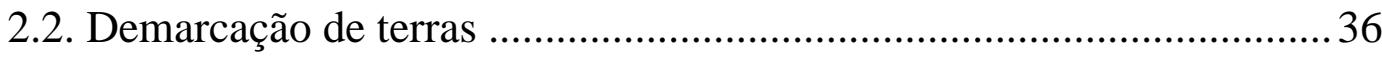

2.3. Desafios da terra indígena .................................................................... 42

2.4. O Poder Legislativo frente às terras indígenas ........................................47

CAPÍTULO 3. POSICIONAMENTO DOS TRIBUNAIS .............................53

3.1. O Poder judiciário e as terras indígenas ..................................................53

3.2. O Supremo Tribunal Federal e as terras indígenas...................................55

3.2.1. Marco temporal e tradicionalidade da ocupação como requisitos de terra indígena e seus efeitos no processo judicial ................................................... 58

3.2. Caso Referência: Raposa Serra do Sol .................................................... 62

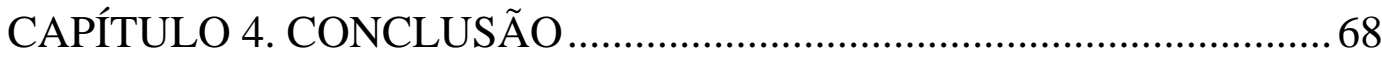

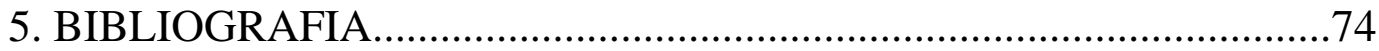




\section{ABREVIATURAS E SIGLAS}

ADCT - Atos das disposições constitucionais transitórias

CRFB - Constituição da República Federativa do Brasil

Funai - Fundação Nacional do Índio

INCRA - Instituto Nacional de Colonização e Reforma Agrária

ONG - Organização não-governamental

PEC - Proposta de emenda a constituição

STF - Supremo Tribunal Federal

TIRSS - Terra Indígena Raposa Serra do Sol 


\section{INTRODUÇÃO}

A abordagem do tema processo de demarcação das terras indígenas através do presente trabalho visa chamar atenção para a demarcação das terras indígenas no Brasil, uma vez que se trata de um tema pouquíssimo debatido tanto no meio acadêmico jurídico. Nas últimas décadas a questão da demarcação de terras tem ensejado inúmeros conflitos, alguns muito violentos que culminam com mortes de índios e não índios. Em complexos contextos de disputa pela posse e propriedade da terra, o tema repercute diretamente nos Poderes Executivo, Legislativo e Judiciário.

No campo jurídico, o tema carece de referência bibliográfica extensa, de modo que esse trabalho foi baseado em pesquisas realizadas na jurisprudência de Tribunais Federais e Superiores e na literatura especializada, especialmente José Afonso da Silva, Darcy Ribeiro, Manuela Carneiro da Cunha e Thais Luzia Colaco. Através destes autores foi possível compreender a dimensão da questão constitucional da demarcação no Brasil. Vale dizer que o debate sobre a demarcação de terras é fundamental para chamar atenção para um procedimento administrativo que não vem sendo corretamente aplicado pelo Poder Executivo Federal e para se construir mecanismos para que ela ocorra, protegendo inúmeras famílias indígenas que desejam ter acesso a posse permanente da terra, garantido no art. 231 da Constituição Federal.

O presente trabalho foi estruturado em quatro capítulos. O primeiro capítulo contextualiza a legislação indígena brasileira desde a chegada do colonizador europeu no Brasil, demostrando como essa legislação alterou a lógica da interação do índio com a terra, inviabilizando a prática de tradições muito antigas praticadas por seus ancestrais. Também veremos como o índio se relaciona com a terra e a importância dela para sua existência individual e coletiva, segundo seus usos, costumes e tradições. 
O segundo capítulo aborda o tratamento dado pela Constituição Federal de 1988 às terras indígenas através do art. 231 do referido diploma legal, que se funda no instituto do indigenato e na legislação infraconstitucional que disciplina o procedimento administrativo da demarcação das terras indígenas. Em seguida foi abordada a precária atuação da administração pública frente às terras indígenas, não respeitando os preceitos da Constituição Federal, com exemplos da atuação do Poder Executivo e o Poder Legislativo na questão.

Após observada a dimensão da demarcação perante os Poderes Executivo e Legislativo, o terceiro capítulo do trabalho aborda os desdobramentos da atuação dos Poderes Executivo e Legislativo no Poder Judiciário. Como se verá, este último, vem sendo frequentemente acionado para dirimir conflitos de posse e conflitos relativos ao procedimento administrativo da demarcação, acarretando na judicilização da demarcação. A investigação da dimensão da questão no Poder Judiciário foi analisada à luz do caso da Terra Indígena Raposa Serra do Sol, com a identificação dos obstáculos na tutela das tradições e direitos dos índios brasileiros. 


\section{CAPÍTULO 1. CONTEXTUALIZAÇÃO DA QUESTÃo INDÍGENA NO BRASIL}

Antes de abordarmos a questão das terras indígenas a partir da Constituição da República Federativa do Brasil de 1988, é necessário entender o significado da terra para os índios antes da chegada portuguesa no continente e como estes interagiam com a mesma através de suas tradições passadas por gerações. Veremos como se deu a chegada dos colonizadores portugueses, apropriando-se da terra, impondo o seu direito e alterando a lógica do uso da mesma. Por fim, observaremos a sequência de legislação que se sucedeu com a chegada portuguesa.

\subsection{Tradição e identidade cultural indígena}

Antes da chegada dos colonizadores europeus na América do Sul todo o continente era habitado apenas por povos indígenas das mais diversas etnias, livres ${ }^{1}$ e sem qualquer restrição ao uso das terras. Ao contrário do que muitos possam pensar, apesar de possuírem aspecto físico, temperamento, inclinação, moral, costumes e modo de vida quase idênticos, muitos grupos indígenas apresentavam línguas distintas e tradições comuns em relação ao uso da terra ${ }^{2}$, conforme relatou o Carlos Frederico Philippe Von Martius:

"Na embarcação em que nós, o dr. Spix eu, exploramos os rios do Brasil, contamos muitas vezes entre 20 remadores índios, somente 3 ou 4 podiam communicar-se numa mesma lingua (...) Que phenomeno enygmatico essa differença de linguas, sendo todos os costumes e habitos os mesmos."

\footnotetext{
${ }^{1}$ COLACO, Thais Luzia. Legislação indígena: os índios e a lei - história e contemporaneidade. In: XII Simpósio Internacional IUH: A experiência missioneira: território, cultura e identidade. São Leopoldo: Casa Leiria, 2010, p. 1.

${ }^{2}$ MARTIUS, Carlos Frederico Von. O Direito entre os indígenas do Brasil. São Paulo: Edições e Publicações Brasil, p. 20.

${ }^{3}$ Naturalista e explorador alemão, em trabalho que aborda a vida dos nativos brasileiros quando em 1817 fez parte de uma comissão organizada pelo governo Austríaco para explorar características botânicas e conduzir estudos zoológicos no Brasil.

${ }^{4}$ Martius, Op. cit., p. 20.
} 
Relatos como esses mostram como existiam grupos étnicos diversos na sociedade indígena e que os europeus não foram capazes de identificar as diversas etnias existentes, já que além de terem sido desprestigiados pelo colonizador, perante estes, os índios não eram seres humanos. ${ }^{5}$

Até onde se sabe, os índios daquela época possuíam um direito oral, sem qualquer forma escrita que obedecia estritamente as tradições passadas por seus ancestrais e normas de convívio instituídas pelos grupos. ${ }^{6}$

Fazendo uma análise sobre tradição à luz do conceito de 'tradição inventada' definida por Eric Hobsbawn ${ }^{7}$, como sendo as várias práticas (atos) sociais constantes que se verificam em um grupo, incluindo tanto as tradições realmente inventadas e tradicionalmente institucionalizadas, quanto as que surgiram de maneira mais difícil de se localizar em um período delimitado, em um determinado momento da história. Nas palavras do autor, as ações dentro das tradições simplesmente são uma continuidade em relação ao passado, que não necessariamente são possíveis de identificar o momento exato de seu nascimento. ${ }^{8}$

Somado à isto, por questões de crença, violar costumes e tradições poderia provocar a ira de deuses, colocando em risco a segurança da coletividade. De modo que, identifica-se que grande parte dos usos e costumes das sociedades primitivas está ligada à religião. ${ }^{9}$

Toda a tradição observada pelos índios brasileiros até o momento da chegada dos portugueses já era consolidada através de um processo que atravessou gerações. Segundo Thais Luzia Colaco, as tradições dos índios pré coloniais, em termos jurídicos, se regiam através de quatro princípios

\footnotetext{
${ }^{5}$ COLACO, Op. cit., p. 2.

${ }^{6}$ Ibid.

${ }^{7}$ Professor de História Econômica e Social do Birbeck College, Universidade de Londres.

${ }^{8}$ Hobsbawm, Eric; Ranger, Terence. A invenção das tradições. Rio de Janeiro: Paz e Terra, 2008, p. 9. "Por tradição inventada, entende-se: (...) um conjunto de práticas, normalmente reguladas por regras tácita ou abertamente aceitas; tais praticas, de natureza ritual ou simbólica, viam inculcar certos valores e normas de comportamento através da repetição, o que implica, automaticamente, uma continuidade em relação ao passado"

${ }^{9}$ COLACO, Op. cit., p. 2.
} 
básicos: o da responsabilidade coletiva, o da solidadariedade, o da reciprocidade e da valoração dos interesses coletivos em detrimento dos individuais. ${ }^{10}$ Esses princípios da tradição indígena se manifestam no relacionamento do índio com a terra e são facilmente observadas quando se analisa o funcionamento das atividades indígenas e da comunidade.

Tratava-se de uma forma organizacional criada pela tradição que trazia ordem social, segurança e coerência para toda a tribo. No entanto, com se verá adiante, é possível afirmar sem dúvidas, que essa ordem organizacional não foi identificada, tampouco respeitada pelos colonizadores europeus, porque entraram no Brasil com o objetivo de dominar e explorar e não reconheceram os nativos da região como seres humanos.

Com bem observou Pero de Magalhães Gandavo, "por muito tempo não se aceitou a existência de um direito nas sociedades indígenas. Desde o descobrimento da América, partindo-se de uma visão etnocêntrica, era consenso que os índios não tinham 'Fé, nem Lei, nem Rei’”."11

\subsubsection{O significado da terra para o índio}

"'Anna Pata Anna Yan, Nossa Terra Nossa Mãe"12

No ano de 1500 diversas tribos ocupavam o litoral brasileiro, dentre elas havia os Tupis, grupo que mais entrou em contato com os portugueses. Habitavam o litoral em áreas que hoje corresponde aos Estados do Rio de Janeiro, Bahia, Maranhão e Pará. ${ }^{13}$ Praticavam as atividades de coleta, caça e pesca sem nenhuma preservação do equilíbrio da natureza. Assim sendo,

\footnotetext{
${ }^{10}$ COLACO, Thais Luzia. Incapacidade indígena: Tutela religiosa e violação do direito guarani nas missões Jesuíticas. Curitiba: Juruá, 2003.

${ }^{11}$ GANDAVO, Pero de Magalhães. Tratado da Terra do Brasil, IN Incapacidade indígena: Tutela religiosa e violação do direito guarani nas missões Jesuíticas. Curitiba: Juruá, 2003. p. 20.

${ }^{12}$ Carta do Conselho Indígena de Roraima.

${ }^{13}$ BUARQUE DE HOLANDA, Sérgio. Historia geral da civilização brasileira: época colonial. São Paulo: Difusão Européia do Livro, 1968, p. 72.
} 
por conta do uso exaustivo da terra, as áreas ocupadas eram abandonadas e as tribos se deslocavam para outras áreas dentro de uma mesma região em busca de um novo solo fértil. O domínio de práticas assegurava a sobrevivência dentro do espaço que ocupavam.

Este espaço de terra constituía o bem maior desta tribo indígena, eis que lhes dava todos os elementos necessários para existência. Uma tribo abrangia um número de unidades menores, denominadas aldeias, que ficavam distanciadas no espaço, mas unidas por parentescos, interesses comuns e similar comunicação com o sagrado. Sobre a ocupação de vastas regiões para obterem alimentos e demais elementos de subsistência, descreve Von Martius:

"Esta idea nítida de uma propriedade determinada da tribu toda, basêa-se principalmente na necessidade de possuir uma certa região de matta para terreno exclusivo de caça porque, ao passo que poucos hectares de terreno cultivado são sufficientes para prover a subsistência de uma communidade numerosa, a caça move-se em um território muito maior. Ás vezes estendem-se taes territórios de caça até além do terreno occupado pela tribu. Os seus limites são rios, montanhas, rochas, cachoeiras e grandes arvores; estes limites basêam-se ora em tradicções, ora em verdadeiros tratados.”

O relato acima permite observar que os índios não impunham limites territoriais formais para delimitação de uma área. O limite era observado através de elementos da natureza, tais como rios e cachoeiras. As áreas eram ocupadas por conta da necessidade de se obter alimentos para subsistência de todo o grupo.

Segundo Sérgio Buarque de Holanda, havia um padrão de cooperação entre as famílias de uma mesma aldeia, que nos permite verificar os princípios da solidariedade, responsabilidade coletiva e valoração dos interesses do grupo. Com observado por Gandavo:

“em cada casa desta vivem todos muito conformes, sem haver nunca entre êles nenhumas diferenças: antes são tão amigos uns dos outros, que o que é de um é de todos, e sempre de qualquer coisa que um coma, por pequena que seja, todos os circunstantes hão de participar dela”. ${ }^{14}$

\footnotetext{
${ }^{14}$ Ibid., p. 73.
} 
Por conta da cooperação e da solidariedade, os produtos da caça, pesca e de atividades agrícolas eram divididos por todos os membros. Acredita-se que o maior motivo de desavença entre os grupos ocorria quando, pouco frequentemente, um indivíduo quebrava a solidariedade. A divisão do trabalho se dava de acordo com o sexo e a idade, onde as mulheres se ocupavam das atividades domésticas e agrícolas enquanto aos homens era atribuída a caça, pesca, sacrifícios e proteção da tribo. Essas relações de interdependência baseadas na tradição imprimiam ordem à comunidade. Todos faziam parte de um movimento maior fundamental para o funcionamento da tribo.

O explorador Von Martius também constatou que, regidos por costumes, possuíam a noção de que tudo era de todos, desse modo, a terra era vista como pertencente a toda comunidade e não apenas de um único indivíduo ou família. Descreveu entendimento da posse de propriedade:

\footnotetext{
"Em toda a extensão que as familias de uma horda occupam numa certa região, é esse território considerado propriedade da communidade. Esta idéa está clara e viva na alma do indio e elle comprehende a propriedade commum como cousa inteiriça, da qual porção alguma pode pertencer a um indivíduo só."15
}

Está claro que a terra tem grande importância para subsistência coletiva, sendo assim, não podia ser atribuída a uma única pessoa, mas a todos do grupo. O indivíduo ali habitava e dali retirava sua subsistência e sua contribuição para o restante do grupo.

Também havia uma tradição espiritual, que criava um olhar do índio sobre a terra que nasceu e habitou. A terra não se caracteriza apenas como local de obtenção de elementos de subsistência como alimentos, vestimentas e artefatos, tampouco como um local apenas destinado a caça e pesca. A terra era mais do que isso, tratava-se de um local sagrado, onde nela nasceram, viveram, morreram e estavam enterrados seus ancestrais. A

\footnotetext{
${ }^{15}$ MARTINS, Op. cit., p. 65.
} 
esse respeito o antropólogo Rubem Almeida ${ }^{16}$ bem observa que no campo espiritual, a tradição da terra indígena, se dá da seguinte forma:

“É como com as plantas. Se uma planta nasce em certo lugar, é dali. Os guarani entendem que pertencem a uma determinada terra - e não que a terra pertence a eles."

Fica claro, a lógica da relação dos índios com a terra, isto é, a forma como eles a vêem e a encaram é no sentido de que não são donos dela, tampouco poderiam ser, porque são eles que pertencem a terra e não a terra que pertence a eles. Além dessa sensação de ligação com a terra que transcende o entendimento do colonizador europeu e das atuais gerações brasileiras não indígenas, a questão da espiritualidade, nas palavras do Ministro Carlos Ayres Britto:

\footnotetext{
“Terra indígena, no imaginário coletivo aborígine, não é um simples objeto de direito, mas ganha a dimensão de verdadeiro ente ou ser que resume em si toda ancestralidade, toda coetaneidade e toda posteridade de uma etnia."18
}

Há um vinculo espiritual muito forte do índio com a terra e com os recursos naturais que ela proporciona. Falar que a terra é elemento sagrado não é uma força de expressão e nem exagero, pois de fato ela é tudo para eles. O índio pré colonial acreditava que seus deuses estavam ligados a elementos da natureza e assim o espaço físico do território seria onde as divindades se manifestavam. A terra não se resume a um lugar de habitação, mas um elemento central da identidade cultural indígena.

Atualmente, a espiritualidade se mantém para muitos povos indígenas e deixar de reconhecer o direito à terra, não implica simplesmente em negar o direito de moradia, mas implica em consequências maiores e desastrosas, tal como a diminuição de populações, a assimilação e perda da

\footnotetext{
${ }_{17}^{16}$ Antropólogo especialista em índios da etnia Guarani.

17 GARRATONI, Bruno. A terra sagrada dos índios. Disponível em $<$ http://super.abril.com.br/cotidiano/terra-sagrada-indios-752921.shtml>. Acesso em 20.03.2015.

${ }^{18}$ Plenário STF, Pet. 3.388 (RR), Min. Rel. Ministro Carlos Ayres Britto, Plenário, Brasília, 19 mar 2009.
} 
sua identidade cultural e tradicional, que está intimamente ligada ao terreno habitado por suas famílias durante gerações.

Nesse sentido, o Ministro Menezes Direito, no julgamento do Caso Raposa Serra do Sol, declarou que - "Não há índio sem terra”"19. Podemos depreender que para o Ministro a importância da terra para o índio se funda na sua própria existência. No caso foi exaustivamente demonstrada a íntima relação que os índios guardam com a terra e como esta é requisito fundamental para a preservação de sua identidade étnica e cultural. Em suas palavras:

“A relação com o solo é marca característica da essência indígena, pois tudo o que ele é, é na terra e com a terra. (...) É nela e por meio dela que eles se organizam. É pisando o chão e explorando seus limites que desenvolvem suas crenças e enriquecem sua linguagem intimamente referenciada à terra." ${ }^{20}$

A mesma interação com a terra foi observada pelo antropólogo Darcy Ribeiro, que após estudos, verificou que as tradições e costumes indígenas estão intimamente atrelados à terra. Assim: “ (...) o índio é ontologicamente terrâneo. É um ser de sua terra. A posse da terra é essencial a sua sobrevivência”.21

Sem ela não poderiam viver, pois não teriam como sobreviver fora das tradições estabelecidas e passadas por seus ancestrais. O vínculo espiritual com a terra e o modo de viver faz com que seja fundamental a manutenção da posse pelo índio.

É possível deduzir que o vínculo espiritual e de ancestralidade não permitem que esses indivíduos ocupem qualquer pedaço de terra, pois eles pertencem ao local onde suas famílias nasceram e viveram. Não poderiam ser simplesmente alocados em uma nova terra, já que esta não expressaria a

\footnotetext{
${ }^{19}$ Voto do Ministro Carlos Alberto Menezes Direito, em favor da Portaria n. ${ }^{\circ}$ 534, que delimitou a Terra Indígena Raposa Serra do Sol, em Roraima. STF, Pet. 3388 (RR).

${ }^{20}$ Plenário STF, Pet. 3.388 (RR), Min. Rel. Ministro Carlos Ayres Britto, Plenário, Brasília, 19 mar 2009.

${ }^{21}$ RIBEIRO, Darcy. A Política Indigenista Brasileira. $1^{\text {a }}$ ed. Rio de Janeiro: Ministério da Agricultura, 1962.
} 
ancestralidade do grupo indígena. No entanto, os colonizadores portugueses não respeitaram essa tradição indígena e, como se verá a seguir, com o objetivo de facilitar a exploração do Brasil e garantir o domínios das terras pela Coroa Portuguesa, esbulharam os índios das terras que tradicionalmente ocupavam e forçaram-nos a uma nova forma de organização terrena, que se dava através de aldeamentos delimitados.

\subsection{A chegada dos colonizadores portugueses}

Acredita-se que a partir de 1500, século XV, após a chegada de Pedro Alvares Cabral, os primeiros contatos entre portugueses e índios em terra brasileira revestiram-se de certa amistosidade. Já naquele momento, Pero Vaz de Caminha escreveu à Corte Portuguesa, informando que não haveria nenhum obstáculo insuperável à conversão e domesticação dos habitantes descobertos no Novo Mundo - "essa gente, é boa e de boa simplicidade. E imprimir-se-a nêles qualquer cunho que lhes quiseram dar". 22

Desde do início, mesmo com um certo grau de amistosidade entre os dois povos, o índio foi visto como um animal que deveria ser domésticado. Em seguida foi identificado como homem, porém humanamente inferior e incapaz.. Nesse sentido:

\footnotetext{
"Chocados com a aparência física e com os costumes indígenas, os europeus os consideraram animais. Após muita discussão concluiu-se que eram homens, mas inferiores e incapazes de se autogovernar, aliás para alguns esta idéia mantém-se até nossos dias. Sob o pretexto de protegê-los, encontrou-se na tutela a justificação legal para dominá-los e administrá-los, transformando a sua cultura sob a égide da civilização ocidental. Não houve nenhuma percepção e entendimento das diferenças étnico-culturais, ambiental e física dos povos americanos. Desde a chegada de Colombo, por acreditar estar nas Índias, classificou indistintamente todos os habitantes do Continente Americano de índios, e esta nomenclatura perdura até hoje.”23
}

\footnotetext{
${ }^{22}$ BUARQUE DE HOLANDA, Op. cit., pp. 27-49.

${ }^{23}$ COLACO, Thais Luzia. Incapacidade indígena: Tutela religiosa e violação do direito guarani nas missões Jesuíticas. Curitiba: Juruá, 2003, pp. 2-3.
} 
Os colonizadores não foram capazes de respeitar as tradições indígenas que davam coerência a todo seu sistema organizacional, já que na Europa predominava o absolutismo monárquico, onde o direito era a lei promulgada pela autoridade real, investido de tal poder por conta da teoria cristã da origem divina. Os colonizadores estavam emergidos no etnocentrismo jurídico, pelo qual toda forma de direito está vinculada a um Estado, não sendo possível aceitar outra forma de direito em uma sociedade ausente de forma estatal. ${ }^{24}$

Sendo visto como um ser humano inferior, no período compreendido entre os anos de 1500 e 1530, período pré colonial, os índios foram atraídos para o escambo. Nessa fase os colonizadores europeus estavam mais interessados na exploração do pau-brasil, árvore nativa brasileira. A exploração dessa árvore foi a primeira atividade econômica empreendida pelos portugueses em território brasileiro. Assim, os índios ficaram responsáveis por cortar as árvores, empilhar e carregar os troncos até os navios portugueses. Em troca da mão de obra, recebiam objetos que não lhes eram comuns, tidos como sem valor para os portugueses, tais como espelhos, apitos, panos, facões, colares, tecidos e roupas. ${ }^{25}$

A exploração do pau-brasil tornou-se posse exclusiva da Coroa Portuguesa e a árvore só poderia ser retirada das matas brasileiras com prévia autorização da mesma. A Coroa não se preocupou em fixar colonos no território brasileiro, as expedições tinham funções exploradoras e militares, o que possibilitava ainda alguma autonomia das tribos indígenas que podiam manter seus costumes e tradições, uma vez que eram maioria e os europeus necessitavam de sua ajuda para obter alimentos e alojamento. ${ }^{26}$

Após 1530, com o início do período colonial, houve uma grande modificação na relação amistosa entre índios e portugueses. Os interesses

\footnotetext{
${ }^{24}$ COLACO, Thais Luzia. Incapacidade indígena: Tutela religiosa e violação do direito guarani nas missões Jesuíticas. Curitiba: Juruá, 2003, p. 21.

${ }^{25}$ VICENTINO, Cláudio; DORIGO, Gianpaolo. História do Brasil. $1^{\text {a }}$ ed. São Paulo: Scipione, 2004, pp. 30-32.

${ }^{26}$ BUARQUE DE HOLANDA, Op. cit., p. 82.
} 
dos colonizadores passaram a se opor radicalmente ao dos indígenas, diante de uma crise portuguesa com o comércio no Oriente ${ }^{27}$ e as frequentes tentativas de invasão por contrabandistas estrangeiros. Por necessidade os portugueses decidiram colonizar efetivamente o Brasil e consolidar sua dominação. ${ }^{28}$ Com isso necessitaram de uma legislação para garantir direitos dos colonizadores frente aos povos nativos. ${ }^{29}$

Os indígenas tiveram suas terras e liberdades confiscadas e, muito frequentemente, suas vidas. Muitos conseguiram fugir do litoral para o interior do Brasil ${ }^{30}$, sendo que àqueles que permaneceram no litoral foram forçados a se submeter à exploração colonial, que teve seu ponto de partida com a primeira expedição de Martim Afonso de Souza. O colonizador recebeu da Coroa Portuguesa amplos poderes para descobrir riquezas, policiar, administrar e principalmente povoar as terras brasileiras. Foi ele o responsável pela distribuição de sesmarias ${ }^{31}$ aos cerca de 400 homens portugueses que compuseram sua expedição, sendo os índios alijados desta repartição.

A colonização de fato teve início com a fundação de vilas e cidades em pontos estratégicos da costa brasileira, formando alianças entre os donatários e grupos indígenas, catequizados por jesuítas. Os padres jesuítas foram de fundamental importância na moderação entre as pretensões dos colonos e as prerrogativas indígenas. ${ }^{32}$ Nessa época, com a decadência da exploração do pau-brasil, iniciou-se a exploração da cana-de-açúcar, o que acarretou na chegada de mais imigrantes estranhos à cultura indígena.

\footnotetext{
27 "No oriente, turcos e indianos atacavam continuamente as fortalezas portuguesas e concorriam com os lusos, reativando antigas rotas comerciais que cruzavam o mar Vermelho e o golfo Pérsico. Acrescenta-se ainda os não raros naufrágios das embarcações portuguesas e os freqüentes ataques dos corsários no oceano Atlântico, que elevavam os riscos e prejuízos e dificultavam o comércio português com o Oriente (...) Ao declínio do comércio oriental, somou-se a ameaça ao domínio português sobre o Brasil, estimulando o rei D. João III a iniciar uma nova política em relação à colônia americana (...)”. Cf. Claudio Vincentino, História do Brasil, p. 69.

${ }^{28}$ Vicentino, Dorigo, Op. cit., p. 67.

${ }^{29}$ COLACO, Thais Luzia. Legislação indígena: os índios e a lei - história e contemporaneidade. In: XII Simpósio Internacional IUH: A experiência missioneira: território, cultura e identidade. São Leopoldo: Casa Leiria, 2010, p. 3.

${ }^{30}$ GARFIELD, Seth. Luta indígena no coração do Brasil. Brasil: Editora Unesp, 2011, p. 10.

${ }^{31}$ Sesmarias definidas como lote de terras, História do Brasil, p. 70.

${ }^{32}$ BUARQUE DE HOLANDA, Op. cit., p. 69.
} 
Com a alteração do centro de interesse comercial português, marcado com o início da agricultura, o índio passou a ser encarado como obstáculo à posse da terra, mão de obra escrava e ameaça à segurança da colônia. Os objetivos do colonizador só poderiam ser alcançados mediante a expropriação territorial e destribalização dos índios locais. Ao desconstruírem as instituições tribais, advindas da tradição, que davam coerência e autonomia ao povo indígena, estes ficariam mais vulneráveis e suscetíveis à dominação do colonizador ${ }^{33}$.

Os jesuítas tiveram um papel fundamental na destribalização consistindo em agentes de assimilação dos índios à civilização cristã. Utilizavam-se de táticas que questionavam a autoridade de líderes tribais (pajés e caciques), a legitimidade de tradições e de rituais antropofágicos. ${ }^{34}$ Foram responsáveis por gerar desequilíbrios na realidade indígena, a medida em que formavam novas aldeias com índios dispostos a aprender seus ensinamentos e retirando mulheres e crianças de suas tribos originárias, acarretando o rompimento do sistema organizacional dos índios.

À luz dos ensinamentos do filósofo francês Michel Foucault ${ }^{35}$, podemos compreender que o movimento realizado pelos jesuítas com as populações indígenas implicava na domesticação dos índios com o costume europeu, impondo o poder do colonizador sobre os colonizados. Assim, para o autor,os jesuítas inseriram processos disciplinares nas realidades indígenas, nascendo uma forma de dominação, que passou a controlar a organização interna, comportamento e linguagem daqueles que se submeteram aos ensinamentos da Igreja.

Para Sérgio Buarque de Holanda, diante da dominação portuguesa, ocorreram três formas de reação ${ }^{36}$ : (i) violenta para preservar a autonomia

\footnotetext{
${ }^{33}$ Ibid. pp. 70-72.

${ }^{34}$ Ibid. P.70.

${ }^{35}$ FOUCAULT, Michel. Vigiar e Punir: Nascimento da Prisão. Petrópolis: Editora Vozes, 2004, pp. 117-120.

${ }^{36}$ BUARQUE DE HOLANDA, Op. cit., p. 83.
} 
indígena $^{37}$, (ii) submissão, seja como aliado ou escravo dos colonos e (iii) migração para áreas onde os colonos não detinham controle. Esta última por sua vez se apresentou como a reação menos eficaz, pois os portugueses possuíam grande mobilidade e frequentemente realizavam expedições rumo ao centro do Brasil. Essas três formas de reação também foram observadas por João Mendes Júnior:

\begin{abstract}
"Os jesuitas attahiram a si os indigenas; e, como consta das chronicas, tinham ao redor da povoação as tribus de Tibiriçá, maiorial de Piratininga, Cayuby, maiorial de Jerybatyba, e Piqueroby, maiorial de Ururay. O primeiro alliou-se logo aos europeus e disciplinou-se completamente com os jesuitas; o segundo era muito velho, ficou em Piratininga, mas o da sua tribu não se sujeitaram facilmente e derramaram-se pelo litoral; o terceiro sempre reclamou a sua autonomia, levantou o brado de guerra e, vencido, preferiu a dispersão a arriscar-se ás desgraças da servidão. Deste ultimo grupo sahiram, em geral, os indios não aldeados (...).”38
\end{abstract}

Os grupos indígenas que não fugiram e permaneceram no litoral foram agrupados, em aldeamentos controlados, organizados e administrados pelos jesuítas. Esses locais não permitiam que os índios vivessem plenamente de acordo com seu modo de vida tradicional observado anteriormente.

Dentro dos aldeamentos foram juntadas diferentes tribos. Isso porque o colonizador acreditava que todos os grupos eram idênticos, desrespeitando as diferenças em suas tradições. Quando as comunidades eram transferidas para um aldeamento limitava-se a observância da amistosidade ou não entre as tribos. Nos aldeamentos os índios não viviam mais para sua própria subsistência e de suas tribos, mas se tornaram mão de obra para o desenvolvimento da economia colonial, servindo os moradores da colônia.

\footnotetext{
${ }^{37}$ Que neste caso temos como exemplo a chamada "Confederação dos Tamoios" - "Na ocasião, ainda que temporariamente, a desvantagem tecnológica dos indígenas podia ser amplamente compensada pela supremacia oriunda da preponderância demográfica e pela iniciativa de movimentos combinada ao ataque simultâneo a diversa posições dos brancos, do litoral ao planalto (...). No entanto, o sucesso dos índios foi parcial e efêmero". BUARQUE DE HOLANDA, Op. cit., p. 85.

${ }^{38}$ MENDES JÚNIOR, João. Os indigenas do Brazil: Seus direitos individuaes e políticos. São Paulo: Typ. Hennies Irmãos, 1912, p. 26.
} 


\subsection{O novo sentido de terra dado pelos portugueses}

A expedição de Martim Afonso de Souza, possuía amplos poderes se comparada as outras expedições portuguesas. Nas palavras de Sérgio Buarque de Holanda "nenhuma expedição teve a importância dessa para o desenvolvimento dos planos de ocupação efetiva da terra"39. Instaurou-se o regime das capitanias hereditárias, com o objetivo de se facilitar o povoamento do Brasil, através de doações de terras a donatários. As capitanias deveriam funcionar com o objetivo de favorecer a metrópole portuguesa, assim:

\footnotetext{
"No acertado entender de modernos historiadores, dava el-rei a terra para o donatário administra-la como província ao invés de propriedade privada. Diz Malheiro Dias: 'O governador hereditário não podia lesar os interêsses e direitos da população. Os impostos eram pagos em espécie. À Coroa pertencia o quinto do ouro e das pedras preciosas (...) o monopólio das drogas e especiarias.”
}

A Coroa portuguesa dividiu o Brasil em capitanias hereditárias com o objetivando que seus donatários promovessem a colonização da área e estabelecessem grandes latifúndios. Eles não podiam de forma alguma partir a capitania, tampouco aliena-las. O direito de modificar a divisão das terras era direito exclusivo do Rei português ${ }^{40}$. Esse novo regime foi regulamentado através de cartas de doação e forais, instrumentos jurídico que continham os direitos e deveres dos donatários. Uma de suas prerrogativas era de doar sesmarias a colonos, propriedades privadas dentro das capitanias, que deveriam ser ocupadas e exploradas no prazo de 5 anos, caso contrário corriam o risco de perdê-las. O donatário também tinha o poder de escravizar índios. ${ }^{41} \mathrm{O}$ regime das capitanias hereditárias não prosperou por falta de investimentos da Metrópole, pela falta de interesse dos donatários e pelos frequentes conflitos com as populações indígenas.

Diante do fracasso do modelo de capitanias, instaurou-se o sistema de governos-gerais, onde a Coroa centralizou a administração da colônia

\footnotetext{
${ }^{39}$ BUARQUE DE HOLANDA, Op. cit., p. 93.

${ }^{40}$ Ibid. p. 100.

${ }^{41}$ VICENTINO, DORIGO, Op. cit, p. 74.
} 
para coordenar a defesa contra ataques indígenas e piratas e efetivar a colonização.

O primeiro governo-geral, de Tomé de Souza, em 1549, dentre suas atribuições, ficou responsável por combater ou fazer alianças com os índios, incluindo a concessão de terras aos indígenas que fossem aliados. Esse governo ficou marcado pela chegada de mais colonos a quem foram doadas sesmarias, para criação de fazendas e pela chegada de escravos africanos.

A exploração da colônia foi intensificada com o estabelecimento de engenhos de açúcar, estaleiros, criação de gados bovinos e produção agrícola. Os índios não possuíam poder sobre as terras, os que não fugiram para o centro do Brasil e permaneceram em aldeamentos organizados pelos jesuítas, viviam praticamente como escravos. Conforme observou Manuela Carneiro da Cunha:

“(...) há vários indícios de que os índios das aldeias acabavam ficando em situação pior do que os escravos: sobrecarregados, explorados, mandados de um lado para outro sem que sua "vontade”, (...) fosse considerada."

Nesse momento a terra brasileira era uma terra de exploração e de propriedade da metrópole portuguesa. A terra já não era mais de propriedade de uso de toda coletividade indígena e seus recursos naturais não eram mais elementos voltados simplesmente para a subsistência humana. Os recursos naturais constituíam meros elementos lucrativos de exploração pela metrópole para possibilitar o desenvolvimento colonial e remeter recursos para a Coroa Portuguesa.

\subsection{Das primeiras legislações sobre a terra indígena}

Com o advento da Carta Régia de 30 de julho de 1609 ficou firmado que os índios possuíam pleno domínio sobre as terras que ocupavam, bem

\footnotetext{
${ }^{42}$ CARNEIRO DA CUNHA, Manuela. História dos índios no Brasil. São Paulo: Companhia das Letras e Secretaria Municipal de Cultura, 1992, p. 121.
} 
como àquelas que lhes foram atribuídas por ocasião dos aldeamentos ${ }^{43}$. Essa regra foi repetida na Carta Régia de 10 de setembro de 1611, que dispôs que:

“ (...) os gentios são senhores de suas fazendas nas povoações, como o são na Serra, sem lhes poderem ser tomadas, nem sobre ellas se lhes fazer molestia ou injustiça alguma; nem poderão ser mudado contra suas vontades das capitanias e lugares que lhes forem ordenados, salvo quando elles livremente o quizerem fazer $(. .)$.

O Regimento das Missões do Estado do Maranhão e Pará de 1668 manteve a regra, declarando que "a justiça não permite, que estes homens sejão obrigados a deyxarem todo, e por todos as terras que habitão”. Já o Alvará Régio de 1680 e a Lei de 06 de junho de 1755 foram mais além, reconhecendo a autonomia dos povos indígenas e reconhecendo serem os índios os "primários e naturais senhores"44 de suas terras. Conjuntamente, ambos dispositivos consagraram pela primeira vez o regime do indigenato, que reconhece o caráter originário e imprescritível dos direitos dos indígenas sobre suas terras.

Em 1718 a Coroa Portuguesa declarou através da Carta Régia de 9 de março que os índios eram livres e isentos da jurisdição portuguesa, sendo vedado obrigar-lhes a saírem das terras que ocupavam para viverem de um modo não condizente com sua realidade tradicional. Observa-se que a legislação colonial era favorável aos índios, no entanto, muito contraditoriamente, ao mesmo tempo que se garantia o domínio indígena sobre a terra, seus direitos e terras não eram respeitados e discutia-se muito a escravidão indígena ${ }^{45}$.

Mesmo com o reconhecimento do direito originário sobre a terra, os índios continuaram a ter seus territórios originais e aldeamentos

\footnotetext{
${ }^{43}$ Carneiro da Cunha, Manuela. Os direitos do índio ensaios e documentos.São Paulo: Ed. Brasiliense S.A., 1987, p. 58.

${ }^{44}$ Parágrafo $4^{\circ}$ do Alvará Régio de 1680.

${ }^{45}$ Cf. Carta Régia de 9 de abril de 1655 e Alvará de 28 de abril de 1688 que permitiam que índios fossem postos como escravos quando prisioneiros de guerra defensiva.
} 
esbulhados $^{46}$. Em 1819 a Coroa legislou no sentido que as terras indígenas seriam inalienáveis, sendo nulas as concessões de sesmarias eventualmente feitas nas terras indígenas, quais não poderiam ser consideradas devolutas ${ }^{47}$.

Com o período imperial o Brasil teve um grande um retrocesso nos direitos indígenas sobre a terra. Os índios deixaram de ser considerados brasileiros. A partir daí o governo imperial instituiu a Lei n. ${ }^{\circ} 601$ de 18 de setembro de 1850, mais conhecida como Lei de Terras, com o objetivo de tentar pela primeira vez organizar a propriedade privada no país. Muitos autores $^{48}$ entendem que essa lei preserva a "propriedade indígena dos territórios ocupados que não necessitam de legitimação de posse, já que seu título legítimo é o indigenato" ${ }^{49}$. João Mendes Júnior nesse sentido entende:

\begin{abstract}
"Quer da letra, quer do espírito da Lei de 1850, se verifica que essa Lei nem mesmo considera devolutas as terras possuídas por hordas selvagens estáveis: essas terras são tão particulares como as possuídas por ocupação legitimável, isto é, originariamente reservadas de devolução, nos expressos termos do Alvará de $1^{\circ}$ de abril de 1680 , que as reservas até na concessão das sesmarias; não há (neste caso) posse a legitimar, há domínio a reconhecer (...)”50
\end{abstract}

Já o Decreto n. ${ }^{\circ} 1.318$ de 1854 que regulamentou a Lei de Terras, definiu:

“Art. 72. Serão reservadas terras devolutas para colonização e aldeamento de indígenas nos distritos onde existem hordas selvagens. (...)

Art. 75. As terras reservadas para colonisação de indígenas, e por elles distribuidas, são destinadas ao seu uso fructo; e não poderão ser alienadas, em quanto o Governo Imperial, por acto especial, não lhes conceder o pleno gozo dellas, por assim o permittir o seu estado de civilização." ${ }^{51}$

Logo, a posse das terras dos aldeamentos era reconhecida como sendo destes, contudo o domínio das terras só lhes seria concedido quando

\footnotetext{
${ }^{46}$ CARNEIRO DA CUNHA, Op. cit., p. 61.

${ }^{47}$ CUNHA, Op. cit., p. 63.

${ }^{48}$ MENDES JÚNIOR, João, CUNHA, Manuela Carneiro da, BANDEIRA, Alípio e MIRANDA, Manoel Tavares da Costa.

${ }^{49}$ CUNHA, Op. cit., p. 67.

${ }^{50}$ MENDES JÚNIOR, Op. cit., pp. 59-60.

${ }^{51}$ CUNHA, Op. cit., p. 63.
} 
houvesse o reconhecimento do seu "estado de civilização". Nesse sentido observa Manuela Carneiro da Cunha:

“ (...) as terras dos aldeamentos acabam sendo tratadas a partir da Lei das Terras como apenas reservadas e destinadas a uma ulterior doação aos índios. É uma primeira expropriação a que se segue a extinção das aldeias e a liquidação de suas terras, sem que a doação se efetive.”

Mesmo com a posse reconhecida juridicamente, os governos locais, que podiam legislar cumulativamente com o Governo Geral sobre matéria indígena $^{52}$, eram constantemente pressionados por arrendatários, para que legislassem em detrimento dos direitos indígenas, com o objetivo de obterem para si as terras indígenas. Em muitos casos ocorreram esbulhos, que consistiam no deslocamento ou concentração de grupos indígenas, de modo a reduzir a extensão da ocupação territorial. Com o passar do tempo, mesmo sem respaldo legal, as terras dos aldeamentos extintos foram consideradas devolutas e passíveis de serem vendidas.

Operou-se a partir da Constituição de 1891 uma verdadeira confusão sobre o regime da terra indígena. Não se sabia se o domínio era do Estado ou dos índios, já que seu direito se fundava no indigenato. Muitos aldeamentos extintos estavam localizados em territórios de ocupação imemorial indígena, logo, fundada em um direito originário não passível de ser devoluta. A confusão ocorreu entre distinguir as terras dos aldeamentos extintos (que seriam devolutas, conforme Constituição de 1891), das terras dos aldeamentos extintos de área de ocupação imemorial (que são reservadas das terras devolutas, conforme preceituou a Lei de Terras).

Somente a partir de 1910, com o Decreto n. ${ }^{\circ}$ 8.072/1910, que foi criada a Secretaria de Proteção ao Índio (posteriormente extinta e transformada na FUNAI), previu-se a demarcação das terras ocupadas pelos índios, seu direito ao usufruto exclusivo e o direito de viverem de

\footnotetext{
52 Por conta do Ato Adicional de 1834.
} 
acordo com sua organização interna, costumes e hábitos, conforme art. $2^{\circ}, \S$ $4^{\mathrm{o}}$ do diploma legal:

“Art. $2^{\circ} \mathrm{A}$ assistencia de que trata o art. $1^{\circ}$ terá por objecto:

(...)

$\S 4^{\circ}$ - Fazer respeitar a organização interna das diversas tribos, sua independência, seus hábitos e instituições, não intervindo para alterá-los senão com brandura e consultando sempre a vontade dos respectivos chefes”.

A Constituição de 1934, previu em seu art. 129 que "será respeitada a posse de terras de silvícolas que nelas se achem permanentemente localizados, sendo-lhes, no entanto, vedado aliená-las.” A posse prevista na Constituição de 1934 foi repetida na Constituição de 1937 em seu art. $154^{53}$ e na Constituição de 1946 em seu art. $216^{54}$.

Já a Constituição de 1967 também previu a posse permanente das terras ocupadas pelos índios e reconheceu o direito deles ao usufruto exclusivo dos recursos naturais da área, assim disciplina:

"Art. 186. É assegurada aos silvícolas a posse permanente das terras que habitam e reconhecido o seu direito ao usufruto exclusivo dos recursos naturais e de todas as utilidades nelas existentes."

Além de reconhecer a posse permanente das terras pelos índios, a Constituição de 1967 incluiu estas terras como bens de domínio da União, senão vejamos:

“Art. 4. Incluem-se entre os bens da União:

(...)

IV - as terras ocupadas pelos silvícolas.”

Observa-se que apesar de inúmeros diplomas legais reconhecerem o direito a posse permanente e ainda reconhecerem que esse direito dos índios se funda no indigenato, sempre houve dificuldade no campo para se garantir a posse das terras tradicionais pelos índios. Como observou Darcy Ribeiro:

\footnotetext{
53 “Art. 154. Será respeitada aos silvícolas a posse das terras em que achem localizados em carácter permanente, sendo-lhes, porem, vedada a alienação das mesmas”

54 “Art. 216. Será respeitada aos silvícolas a posse das terras onde se achem permanentemente localizados, com a condição de nato a transferirem”
} 
"No plano legal, o índio sempre teve reconhecido seu direito à terra. Esta prerrogativa data de um alvará de 1680, que os define como 'primários e naturais senhores dela'. Êste direito é confirmado e ampliado pela Lei n. ${ }^{\circ}$ 6, de 1755 e por tôda a legislação posterior."

Nas décadas seguintes o processo de exploração e segregação dos povos indígenas continuaram sob a forma da expansão das fronteiras agrícolas. Os interesses de exploração econômica e o interesse público nessas terras inclusive pela administração pública, serviram de pretexto para expulsar os índios de seus territórios tradicionais.

${ }^{55}$ RIBEIRO, Darcy. A política indigenista brasileira. Rio de Janeiro: Ministério da Agricultura, 1962, p. 100. 


\section{CAPÍTULO 2. AS TERRAS INDÍGENAS E A CONSTITUIÇÃO FEDERAL DE 1988}

Observada as transformações ocorridas no âmbito da natureza jurídica e no regime jurídico da terra desde a chegada portuguesa no Brasil, este capítulo se propõe em analisar como o instituto da terra indígena é regido pela legislação vigente. Com uma análise do regime jurídico das terras indígenas adotado pelo Estado brasileiro desde a Constituição de 1988, seus mecanismos, eficácia e necessidade para o reconhecimento da cultura e tradição indígena. Analisar-se-a, se, de fato, o regime atual atende as necessidades indígenas, suprindo seus anseios e viabilizando o exercício de outros direitos fundamentais previstos na Constituição Federal de 1988, afim de preservar sempre a cultura e a tradição dos povos. Por fim, será visto o papel do Poder Executivo no procedimento da demarcação de terras e como vem atuando o Poder Legislativo frente os direitos indígenas constitucionalmente reconhecidos pelo poder constituinte originário.

\subsection{A terra indígena segundo a Constituição Federal de 1988}

Para se entender o regime jurídico da terra indígena adotado pela Constituição da República Federativa do Brasil é fundamental analisarmos os artigos 231 e o art. 20, XI do referido diploma legal. O primeiro reconheceu ao índio brasileiro os direitos originários sobre as terras que tradicionalmente ocupam e determinou que compete à União Federal demarcar tais terras, bem como proteger e fazer respeitar seus bens. Também reconheceu como legítima a organização social, os costumes, as línguas, crenças e tradições indígenas. E, o segundo, definiu que são bens da União as terras tradicionalmente ocupadas pelos índios. Desse modo, dispõe a Constituição:

“Art. 231. São reconhecidos aos índios sua organização social, costumes, línguas, crenças e tradições, e os direitos originários sobre as terras que tradicionalmente 
ocupam, competindo à União demarcá-las, proteger e fazer respeitar todos os seus bens.”

Ao reconhecer os direitos originários dos índios sobre as terras que tradicionalmente ocupam - terras de domínio público (cf. art. 20, XI da CRFB) - a Constituição Federal consagrou uma relação jurídica fundada no instituto do indigenato.

O indigenato é fonte primária e congênita da posse territorial indígena, não podendo ser confundido com nenhuma forma de ocupação, nem está sujeito a legitimação, pois se funda em um direito originário. Sendo assim, sua aquisição não se assemelha de forma alguma com o instituto do usucapião do Direito Civil, pois, como direito originário, não necessita de lapso temporal de ocupação da terra para sua configuração. Nesse sentido, João Mendes Júnior assevera:

“(...) o indigenato, além desse ius possessionis, tem o ius possidendi, que já lhe é reconhecido e preliminarmente legitimado, desde o Alvará de $1^{\circ}$ de abril de 1680 como direito congênito. (...) como título de aquisição, só pode ter por objeto as coisas que nunca tiveram dono. A ocupação é uma apprehensio rei nullis ou rei derelictae (...) ora, as terras de índios, congenitamente apropriadas, não podem ser consideradas nem como res nullius, nem como res derelictae; por outra, não se concebe que os índios tivessem adquirido, por simples ocupação, aquilo que lhes é congênito e primário." ${ }^{56}$ (grifos do autor)

Desse modo, a relação entre os índios e suas terras, congenitamente possuídas, não poderiam ser regidas pelas normas do Direito Civil, pois, conforme salienta José Afonso da Silva ${ }^{57}$, "sua posse extrapola da órbita puramente privada, porque não é e nunca foi uma simples ocupação da terra para explorá-la, mas base de seu habitat, no sentido ecológico de interação do conjunto de elementos naturais e culturais que propiciam o desenvolvimento equilibrado da vida humana."

Sendo o art. 231 da CRFB a base reguladora de toda discussão sobre a posse e a propriedade da terra indígena, nascem dois desafios a respeito

\footnotetext{
${ }^{56}$ MENDES JÚNIOR, Op. cit., p. 57.

${ }^{57}$ SILVA, José Afonso da. Curso de Direito Constitucional Positivo. Brasil: Malheiros, 2014, p. 874.
} 
da interpretação da norma. Em primeiro lugar, se faz necessário o entendimento do que seriam os chamados direitos originários reconhecidos pelo poder constituinte aos índios e, em segundo lugar, o que podemos chamar de terras que tradicionalmente ocupam.

Por direitos originários, entendemos um direito congênito dos indígenas sobre as terras que ocupam, sendo este um direito que não depende de reconhecimento estatal ou formal, porque os índios possuem o direito sobre as terras que tradicionalmente ocupam mesmo que o Governo Federal, incumbido da atividade de demarcar as terras, não o faça. Nas palavras de Daniel Sarmento ${ }^{58}$, “tais direitos são, portanto, preexistentes em relação a qualquer ato estatal, que se limita a reconhecê-los." ${ }^{59}$ No mesmo sentido, Raimundo Sérgio Barros Leitão, senão vejamos:

“(...) presentes os elementos necessários para definir uma determinada sorte de terra como indígena (quais sejam, aqueles estabelecidos no $\S 10$ ), o direito à ela por parte da sociedade indígena que a ocupa, existe e se legitima independentemente de qualquer ato constitutivo." ${ }^{\circ 0}$

No mesmo sentido a jurisprudência vem se manifestando. A Quinta Turma do Tribunal Regional Federal da $1^{\mathrm{a}}$ Região, teve o seguinte entendimento:

“(...) os direitos dos índios sobre as terras que tradicionalmente ocupam são, conforme entendimento jurisprudencial sedimentado, constitucionalmente reconhecidos e não simplesmente outorgados, com o que o ato de demarcação se orna de natureza declaratória, e não propriamente constitutiva. Ato declaratório de uma situação jurídica ativa preexistente. Essa a razão de a Carta Magna havêlos chamado de "originários", a traduzir um direito mais antigo do que qualquer outro, de maneira a preponderar sobre pretensos direitos adquiridos, mesmo os materializados em escrituras públicas ou títulos de legitimação de posse em favor de não-índios." ${ }^{\prime 1}$

\footnotetext{
${ }^{58}$ Procurador Geral da República

${ }^{59}$ SARMENTO, Daniel. Nota Técnica: A PEC 215/00 e as Cláusulas Pétreas. Disponível em $<$ http://noticias.pgr.mpf.mp.br/noticias/noticias-do-site/copy_of_indios-eminorias/portal_factory/copy_of_pdfs/nota-pec-215-final-1-1.pdf>, p. 15. Acesso em 05.04.2015. ${ }^{60}$ LEITÃO, Raimundo Sérgio Barros. Natureza jurídica do ato administrativo de reconhecimento de terra indígena - a declaração em juízo. In: Juliana Santilli (Coord.), Os Direitos Indígenas e a Constituição. Porto Alegre: Sergio Antonio Fabris Editor, 1991, p. 67.

${ }^{61}$ TRF1, Apelação Cível 00003395220054013901, Desembargadora Federal Selene Maria de Almeida, Brasília, 07 abril 2014.
} 
Em acórdão paradigma, o Supremo Tribunal Federal, em processo sob relatoria do Ministro Carlos Ayres Britto, definiu:

\begin{abstract}
“No ponto, afirmou que o termo 'originários', contido no art. 231 da CF, traduz uma situação jurídico-subjetiva mais antiga do que qualquer outra, de forma a preponderar sobre eventuais escrituras públicas ou títulos de legitimação de posse em favor de não-índios. Tal termo, continuou, é sinônimo de primevo, porque revelador da primeira de todas as formas de cultura e civilização genuinamente brasileiras, digna de uma qualificação jurídica tão elevada que a Constituição estabeleceu que 'os direitos originários' sobre as terras indígenas são reconhecidos e não outorgados ou concedidos.”62
\end{abstract}

Constata-se portanto que a jurisprudência vem entendendo que o direito dos índios é um direito originário, não necessitando de reconhecimento estatal sobre as terras que tradicionalmente ocupam. O direito sendo originário transcende a posse e a propriedade, prevalecendo sobre quaisquer institutos de Direito Civil.

Superada esta primeira discussão, cabe a análise, sobre o prisma constitucional, do que seriam as terras tradicionalmente ocupadas. A Assembléia Constituinte previu:

\begin{abstract}
“Art. 231. São reconhecidos aos índios sua organização social, costumes, línguas, crenças e tradições, e os direitos originários sobre as terras que tradicionalmente ocupam, competindo à União demarcá-las, proteger e fazer respeitar todos os seus bens.

$\S 1^{\circ}$ São terras tradicionalmente ocupadas pelos índios as por eles habitadas em caráter permanente, as utilizadas para suas atividades produtivas, as imprescindíveis à preservação dos recursos ambientais necessários a seu bemestar e as necessárias a sua reprodução física e cultural, segundo seus usos, costumes e tradições.” (grifos meus)
\end{abstract}

Para José Afonso da Silva ${ }^{63}$, a base para o conceito de terra tradicionalmente ocupada, se funda em quatro condições que se fazem necessárias em cada caso concreto, onde nenhuma é suficiente para caracterizar ocupação tradicional se não estiverem preenchidos todos os quatro requisitos.

\footnotetext{
${ }^{62}$ STF, Petição 3.388, Rel. Ministro Carlos Ayres Britto, Brasília, 19 março 2009.

${ }^{63}$ SILVA, Op. cit., pp. 872-873.
} 
Para configuração de terra tradicionalmente ocupadas:

(i) as terras devem ser habitadas em caráter permanente;

(ii) as terras devem ser utilizadas pelos índios no desenvolvimento de suas atividades produtivas;

(iii) as terras devem ser imprescindíveis para a preservação dos recursos ambientais que se fazem necessários a seu bem-estar e;

(iv) as terras devem ser necessárias para sua reprodução física e cultural, segundo seus usos, costumes e tradições.

Para o autor, ao contrário do caráter temporal que terras tradicionalmente ocupadas pressupõe, não haveria no texto legal relação de tempo de ocupação na terra, já que o termo tradicionalmente refere-se ao modo tradicional de ocupação, assim considerado o modo como os índios interagem com o local e fazem uso da terra. Trata-se de requisito mínimo de distinção entre o regime jurídico da terra indígena e a posse do Direito Civil.

Isto porque o poder constituinte originário teve por base a ocupação indígena para fins de exercício de suas tradições, não instituindo o requisito de uma ocupação imemorial, isto é, uma ocupação de época remota que já não se sabe desde quando um grupo indígena estaria no local. Estabelecer um critério temporal para caracterização de uma terra tradicionalmente ocupada seria incompatível com o reconhecimento dado pela Constituição dos direitos originários sobre elas, pois estaríamos falando do instituto do usucapião, que não é aplicável ao indigenato.

Tendo em vista os conceitos constitucionais de direito originário e de terra tradicionalmente ocupada, o $\S 2^{\circ}$ do art. 231 da CRFB dispõe:

“Art. 231. São reconhecidos aos índios sua organização social, costumes, línguas, crenças e tradições, e os direitos originários sobre as terras que tradicionalmente ocupam, competindo à União demarcá-las, proteger e fazer respeitar todos os seus bens.

(...)

$\S 2^{\circ}$ As terras tradicionalmente ocupadas pelos índios destinam-se a sua posse permanente, cabendo-lhes o usufruto exclusivo das riquezas do solo, dos rios e dos lagos nelas existentes".

O Poder Constituinte destinou as terras tradicionalmente ocupadas pelos índios à sua posse permanente, concedendo-lhes o usufruto exclusivo 
das riquezas naturais do solo, rios e lagos existentes nos locais ocupados, visando uma posse para o futuro. Observa José Afonso da Silva:

\begin{abstract}
"Quando a Constituição declara caber aos silvícolas a posse permanente das terras por eles habitadas, isto não significa um simples pressuposto do passado como ocupação efetiva, mas, especialmente, uma garantia para o futuro, no sentido de que essas terras inalienáveis são destinadas para sempre, ao seu habitat" ${ }^{\text {"64 }}$ (grifos do autor)
\end{abstract}

Também vislumbra que a posse atribuída aos índios não tem o mesmo condão do Direito Civil. Em suas palavras, trata-se de:

“(...) em substância, aquela possessio ab origine que, no início, para os romanos, estava na consciência do antigo povo, e era não a relação material de homem com a coisa, mas um poder (...) João Mendes Júnior lembrou que a relação do indígena com suas terras não era apenas um ius possessionis, mas também um ius possidendi, porque ela revela também o direito que têm seus titulares de possuir a coisa, com o caráter de relação jurídica legítima e utilização imediata."65

O reconhecimento da posse permanente também independe de demarcação, pois, como amplamente abordado, trata-se de um direito originário $^{66}$. O art. 23 da Lei Federal n. ${ }^{\circ}$ 6.001/73 (Estatuto do Índio) define a posse indígena como sendo:

“a ocupação efetiva da terra, que, de acordo com os usos, costumes e tradições tribais, detém e onde habita ou exerce atividade indispensável à sua subsistência ou economicamente útil”.

É certo ainda que a posse permanente se faz fundamental para a sobrevivência dos índios, permitindo que possam viver segundo seus costumes e tradições. Nas palavras de Darcy Ribeiro:

“A posse de um território tribal é condição essencial à sobrevivência dos índios. (...) ela opera como barreira à interação e à incorporação. Permitindo ao índio refugiar-se num território onde pode garantir ao menos sua subsistência, faculta-

\footnotetext{
${ }^{64}$ Tourinho Neto, Fernando da Costa. Os direitos originários dos índios sobre as terras que ocupam e suas consequências jurídicas, IN Os Direitos Indígenas e a Constituição. Ed. Núcleo de Direitos Indígenas. Porto Alegre, 1993.

${ }^{65}$ SILVA, Op. cit., p. 875.

${ }^{66}$ Ibid. p. 876.
} 
lhe escapar às compulsões geradas pela estrutura agrária vigente, as quais, de outro modo, o compeliriam a incorporar-se à massa de trabalhadores sem terra. ${ }^{, 67}$

Consequentemente, com a posse permanente da terra, é direito dos povos indígenas, o usufruto exclusivo das riquezas do solo, dos rios e dos lagos existentes no local. O usufruto indígena, assim como a posse, também não se confunde com o conceito do Direito Civil, já que, ao contrário deste, trata-se de um usufruto originário, anterior à propriedade, de uso perpétuo, que não se extingue diante das hipóteses previstas na legislação civil. Apesar da Constituição outorgar exclusivamente aos índios a posse permanente e o usufruto exclusivo das terras tradicionalmente habitadas, a propriedade das terras indígenas é da União, assim estabelecido no art. 20, XI da CRFB. A esse respeito observa Fernando da Costa Tourinho Neto:

“Não sendo os índios proprietários das terras que ocupam, não podem transferilas, aliená-las. Nem o domínio, que não têm, nem a posse. Nem a posse uma vez que a Constituição afetou tais terras à utilização pelos índios. Só o indígena pode utilizá-la., ${ }^{6}$

Por força da norma constitucional, os índios não possuem a propriedade das terras que ocupam e não podem delas dispor, porque estas são patrimônio da União. Nesse mesmo sentido, Aliomar Baleeiro entendeu que:

“(...) as terras indígenas são do domínio público e não do privado, mas não de uso comum do povo e sim dominicais, constituindo patrimônio da União, pois desde a Constituição de 1967 (art. 4º inciso IV), estão incluídas entre os bens da União. Reiteraram essa disposição a Constituição de 1969 (art. 4º, inciso XI) e a de 1988 (art. 20, inciso XI)",69 (grifo do autor)

A proteção constitucional dada as terras indígenas fica ainda mais evidente quando esta demonstra que a terra é destinada apenas aos índios para seus usos, costumes e tradições e que, conforme o $\S 3^{\circ}$ do art. 231:

\footnotetext{
${ }^{67}$ RIBEIRO, Op. cit., p. 143.

${ }^{68}$ TOURINHO NETO, Op. cit., p. 36.

${ }^{69}$ Ibid.
} 


\begin{abstract}
“Art. 231. (...)
$\S 3^{\circ} \mathrm{O}$ aproveitamento dos recursos hídricos, incluídos os potenciais energéticos, a pesquisa e a lavra das riquezas minerais em terras indígenas só podem ser efetivados com autorização do Congresso Nacional, ouvidas as comunidades afetadas, ficando-lhes assegurada participação nos resultados da lavra, na forma da lei." (Grifo meu)
\end{abstract}

No mesmo caminho para proteção do uso da terra apenas por indígenas, o $\S 6^{\circ}$ do art. 231 constitui a nulidade dos atos que tenham por objeto a ocupação, o domínio e a posse das terras indígenas, dispondo que:

“Art. 231 (...)

$\S 6^{\circ}$ São nulos e extintos, não produzindo efeitos jurídicos, os atos que tenham por objeto a ocupação, o domínio e a posse das terras a que se refere este artigo, ou a exploração das riquezas naturais do solo, dos rios e dos lagos nelas existentes, ressalvado relevante interesse público da União, segundo o que dispuser lei complementar, não gerando a nulidade e a extinção direito a indenização ou a ações contra a União, salvo, na forma da lei, quanto às benfeitorias derivadas da ocupação de boa fé.” (Grifo meu)

Mesmo sendo proprietária das terras indígenas, conforme dito anteriormente, a União não tem poder para aliená-las, mesmo que respeitando as normas que regulam a alienação de bens públicos. Isso porque a Constituição estabeleceu no $\S 4^{\circ}$ do art. 231 que as terras indígenas são inalienáveis, indisponíveis e também que os direitos sobre elas são imprescritíveis. Observa Fernando da Costa Tourinho Neto que:

“A afetação é constitucional. Logo, só por emenda constitucional pode ser desconstituída. Assim não pode a norma infraconstitucional alterar esta destinação." ${ }^{, 0}$

Conclui-se portanto que a Constituição Federal recepcionou um regime jurídico especial para as terras indígenas, fundado no indigenato, que não se enquadra na concepção clássica de propriedade do direito civil. Mesmo se tratando de um bem público, de domínio e de propriedade da União, ele é indisponível e inalienável, cabendo à administração pública apenas o dever de garantir a integridade da terra e sua posse pelas

\footnotetext{
${ }^{70}$ Tourinho Neto, Op. cit., p. 37.
} 
populações indígenas, para que estes consigam utilizar a terra segundo seus usos, costumes e tradições.

Com efeito, os índios possuem um direito sobre as terras que tradicionalmente ocupam, sendo deles a posse permanente do local e o direito de usufruto de todos os recursos naturais nela presentes, sendo vedada a presença de terceiros que desejam empreender atividades econômicas.

Para garantia da posse indígena é necessária que seja procedida a demarcação dessas terras pelo Poder Executivo, evidenciando os limites territoriais e barrando a invasão das áreas indígenas.

\subsection{Demarcação de terras}

A demarcação das terras indígenas tem previsão no artigo 231 da CFRB, já transcrito, que conferiu à União Federal o dever de demarcar as terras tradicionalmente ocupadas pelos índios, o dever de proteger e de se fazer respeitar todos os bens indígenas.

O objetivo principal é a preservação e proteção da cultura e tradição das populações indígenas, permitindo que possam viver na terra segundo seus usos, costumes e tradições, com garantia de que ninguém alheio a elas tomará para si a posse. Ela evita que não índios tomem para si a posse terra ou destruam os recursos naturais nelas presentes que são fundamentais para o bem-estar, reprodução física e cultural indígena.

Ademais a demarcação não viabiliza apenas a subsistência indígena conforme seus usos, costumes e tradições, mas traz também inúmeros benefícios para toda a sociedade brasileira, pois contribui com o ordenamento fundiário do Governo Federal, ajudando na redução de conflitos e disputas de terra, facilitando o desempenho das atribuições constitucionais previstas para Estados e Municípios e constituindo ainda um espaço vivo de aplicação do princípio da função social da propriedade pública e da posse. 
Quando identificada que determinada área está dentro de um espaço territorial estadual e municipal, cada um desses entes poderão desenvolver políticas públicas específicas para os povos indígenas existentes dentro de sua jurisdição e facilitará o repasse dos recursos federais destinados às terras indígenas. Sendo assim, a demarcação permite que índios brasileiros possam viver em condições mais dignas, no sentido da redução de sua histórica situação de vulnerabilidade, possibilitando a concretização dos direitos e garantias fundamentais concedidos a todos os cidadãos brasileiros, previstos no art. $5^{0}$ da Constituição Federal, já que viabiliza os direitos sociais fundamentais que constituem o direito à cidade ${ }^{71}$, por exemplo:

“(...) repasses relacionados à gestão territorial e ambiental de terras indígenas, repasses relacionados à educação escolar indígena, recursos relacionados às políticas habitacionais voltadas às terras indígenas, recursos destinados a ações de etnodesenvolvimento, fomento à produção indígena e assistência técnica agrícola em terras indígenas." ${ }^{72}$

Cabe ressaltar que a demarcação garante a diversidade étnica e cultura nacional, enriquecendo o patrimônio cultural brasileiro. Um bem nacional que deve ser tutelado pelo Estado, consoante artigos 24, VII, 215 e 216 da $\mathrm{CFRB}^{73}$. Nesse sentido:

“(...) a proteção ao patrimônio histórico e cultural brasileiro é dever da União e das Unidades Federadas, conforme disposto no Art. 24, inciso VII da Constituição da República Federativa do Brasil de 1988. As terras indígenas são áreas fundamentais para a reprodução física e cultural dos povos indígenas, com

\footnotetext{
${ }^{71}$ Conceito de cidade no Estatuto da Cidade, Lei n. ${ }^{\circ}$ 10.257/2001, não diz respeito apenas às áreas urbanas mas também rurais.

${ }^{72}$ Funai. Por que demarcar?, disponível em <http://www.funai.gov.br/index.php/2014-02-07-1325-20> acesso 18.04.2015.

73 “Art. 215. O Estado garantirá a todos o pleno exercício dos direitos culturais e acesso às fontes da cultura nacional, e apoiará e incentivará a valorização e a difusão das manifestações culturais. § $1^{\circ}$ - O Estado protegerá as manifestações das culturas populares, indígenas e afro-brasileiras, e das de outros grupos participantes do processo civilizatório nacional. (...) Art. 216. Constituem patrimônio cultural brasileiro os bens de natureza material e imaterial, tomados individualmente ou em conjunto, portadores de referência à identidade, à ação, à memória dos diferentes grupos formadores da sociedade brasileira, nos quais se incluem: I - as formas de expressão; II - os modos de criar, fazer e viver; III - as criações científicas, artísticas e tecnológicas; IV - as obras, objetos, documentos, edificações e demais espaços destinados às manifestações artístico-culturais; V - os conjuntos urbanos e sítios de valor histórico, paisagístico, artístico, arqueológico, paleontológico, ecológico e científico.”
} 
a manutenção de seus modos de vida tradicionais, saberes e expressões culturais únicos, enriquecendo o patrimônio cultural brasileiro."74

Como procedimento administrativo a demarcação, constitui um ato meramente declaratório e não constitutivo, porque as terras tradicionalmente ocupadas são um direito originário dos povos indígenas, conforme previu o legislador constituinte.

Existem ainda outras formas de regularização fundiária das terras indígenas, como as reservas indígenas ${ }^{75}$ e as terras dominiais ${ }^{76}$, no entanto, será abordado apenas o procedimento de demarcação prevista na Lei Federal n. ${ }^{\circ}$ 6.001/73 (Estatuto do Índio), art. 19, a seguir transcrito:

“Art. 19. As terras indígenas, por iniciativa e sob orientação do órgão federal de assistência ao índio, serão administrativamente demarcadas, de acordo com o processo estabelecido em decreto do Poder Executivo.

$\S 1^{\circ}$ A demarcação promovida nos termos deste artigo, homologada pelo Presidente da República, será registrada em livro próprio do Serviço do Patrimônio da União (SPU) e do registro imobiliário da comarca da situação das terras.”

Em linhas gerais o dispositivo estabelece que a demarcação deve ser feita pelo órgão federal de assistência ao índio, no caso a Funai, e posteriormente homologada pelo Presidente da República. A regulamentação deste artigo está prevista no Decreto n. ${ }^{\circ}$ 1.775/1996, que traz um procedimento administrativo para identificar e estabelecer os

\footnotetext{
${ }^{74}$ Funai. Por que demarcar?, disponível em <http://www.funai.gov.br/index.php/2014-02-07-1325-20> acesso 18.04.2015.

75 "São terras doadas por terceiros, adquiridas ou desapropriadas pela União, que se destinam à posse permanente dos povos indígenas. São terras que também pertencem ao patrimônio da União, mas não se confundem com as terras de ocupação tradicional. Existem terras indígenas, no entanto, que foram reservadas pelos estados-membros, principalmente durante a primeira metade do século XX, que são reconhecidas como de ocupação tradicional." Exemplo destas são as reservas indígenas de Aconã (Alagoas), Águas Claras (Santa Catarina), Aldeia Kondá (Santa Catarina), Vargem Alegre (Bahia), Takuari (São Paulo), Taba dos Anacé (Ceará) e Cinta Vermelha Jundiba (Minas Gerais), conforme <http://www.funai.gov.br/index.php/indios-nobrasil/terras-indigenas> , acesso em 19.05.2015.

76 "São as terras de propriedade das comunidades indígenas, havidas, por qualquer das formas de aquisição do domínio, nos termos da legislação civil.” Exemplos, Kaxinawá Seringal Independência (Acre), Marrecas (Paraná), Mata da Cafurna (Alagoas), Nova Jacundá (Pará), Rodeador (Maranhão) e Trocará (Pará), conforme < $<$ http://www.funai.gov.br/index.php/indios-nobrasil/terras-indigenas $>$, acesso em 19.05.2015.
} 


\section{limites de abrangência dos territórios tradicionalmente ocupados pelos} povos indígenas. $^{77}$

O estudo sobre o referido Decreto permitiu observar, em síntese, nove etapas a serem cumpridas no processo da demarcação de terras indígenas, quais sejam:

a) Primeiramente inicia-se o processo com estudos de identificação e delimitação das terras. Onde devem ser conduzidos estudos de natureza etnohistórica, sociológica, jurídica, cartográfica, ambiental que deverão ser desenvolvidos por antropólogo de qualificação reconhecida, nomeado pela Funai, conjuntamente com um grupo técnico especializado, preferencialmente composto por membros do próprio órgão, que deverão entregar seus trabalhos dentro do prazo fixado através de portaria editada pelo órgão;

b) Concluídos os estudos de identificação e delimitação da área, tendo o relatório sido aprovado pela Funai, este deverá ser publicado no Diário Oficial da União e no Diário Oficial da unidade federada onde se localizar a área sob demarcação. Desde o início do procedimento demarcatório até 90 dias após a publicação os interessados ou entes federativos onde localizam-se as terras tradicionalmente ocupadas poderão se manifestar, apresentando a Funai, qualquer prova que se faça pertinente (laudos, fotografias, documentos, títulos dominais e etc.), para pleitear eventual indenização ou para apontar vícios no relatório desenvolvido pela equipe técnica;

c) Superada a fase do contraditório administrativo, ocorre a declaração dos limites territoriais pelo Ministro de Estado da Justiça, órgão auxiliar do Poder Executivo Federal. Encerrando-se os 90 dias após a publicação nos diários oficiais, contam-se mais 60 que ao encerrados, a Funai deverá encaminhar o procedimento, relatórios e todas as provas apresentadas por eventuais interessados, ao Ministro de Estado da Justiça, que em 30 dias contados do recebimento do procedimento demarcatório decidirá determinando a demarcação da terra e seus limites, prescreverá diligências que se façam necessárias ou desaprovará a identificação da terra, mediante decisão fundamentada, alegando o não atendimento do disposto no art. 231 da CFRB. Com a declaração dos limites territoriais aprovada, o Ministro deve editar uma portaria;

d) Após a declaração dos limites territoriais pelo Ministro da Justiça, iniciase a demarcação física da área de competência da Funai, que pode instalar placas e cercas ${ }^{78}$ na região evitando entrada de estranhos no local;

e) Após a demarcação física, deve haver um levantamento fundiário de avaliação de benfeitorias implementadas por eventuais ocupantes não-índios, a cargo da Funai e do INCRA;

f) O Presidente da República deverá homologar a demarcação mediante Decreto;

\footnotetext{
77 Funai. Entenda o processo de demarcação. Disponível em $<$ http://www.funai.gov.br/index.php/2014-02-07-13-24-53> acesso em 17.04.2015.

${ }^{78}$ Como ocorreu no caso da demarcação das terras tradicionalmente ocupadas por índios na região do Rio Negro, assim "A execução dos trabalhos foi dividida entre o Governo Federal, através da FUNAI, que contratou a Pórticos Engenharia Ltda. Coube à Pórtico Engenharia Ltda., de Manaus, contratada pela FUNAI, o rastreamento e materialização de 38 pontos geodésicos, com a abertura de clareiras e colocação de marcos e placas”. Pedro Garcia, líder indígena do alto Rio Negro em, $O$ movimento indígena e a demarcação das terras, p. 40.
} 
g) Com a homologação pelo chefe do Poder Executivo Federal, inicia-se a retirada dos ocupantes não índios das terras, com a indenização das benfeitorias consideradas de boa-fé e o reassentamento destes pelo INCRA;

h) Em seguida deve haver o registro cartorário das terras. Após a publicação do decreto de homologação da terra demarcada, a Funai possui o prazo de 30 dias para registrar a homologação no respectivo cartório imobiliário e na Secretaria do Patrimônio da União do Ministério da Fazenda; e

i) Por fim, em se tratando de terra indígena para proteção de povos isolados a Funai deverá instituir interdição dessas áreas, podendo disciplinar sobre o transito de pessoas nesses territórios ${ }^{79}$.

Três etapas nesse procedimento frequentemente geram obstáculos que comprometem o andamento do processo de demarcação. Primeiramente, reside na condução dos estudos da Funai, considerando os prazos para apresentação dos estudos, a alta complexidade e a burocracia administrativa que não observam os prazos legais e acabam demorando anos para serem concluídos. ${ }^{80}$ Além disso membros da sociedade civil apontam a existência de um possível esvaziamento da Funai por parte do Governo Federal, ${ }^{81}$ que vem diminuindo verbas e o quadro de funcionários. O segundo problema está na fase do contraditório administrativo, ${ }^{82}$ que é constantemente alvo de recursos judiciais ${ }^{83}$ por pessoas interessadas

79 FUNAI. Entenda o processo de demarcação. Disponível em < http://www.funai.gov.br/index.php/2014-02-07-13-24-53> acesso em 17.04.2015.

${ }^{80}$ LIMA, Manoel S. De. Demarcação de terras: impactos e desafios na construção da cidadania dos povos indígenas. In Demarcando terras indígenas II, organizado por Márcia Maria Gramkow. Brasília: Funai, 2002, p. 30.

${ }^{81}$ FONTENELE, Cristina. Governo federal é refém do agronegócio e anti-indígena, denuncia bispo do Xingu. Disponível em $\quad \underline{\text { http://www.cimi.org.br/site/pt- }}$ br/?system=news\&conteudo_id=8103\&action=read $>$, acesso em 07.05.2015.

82 “A demarcação de terras indígenas é a culminação de um processo administrativo que envolve diretamente a tutela de direitos fundamentais de comunidades indígenas e de terceiros interessados. Por isso, não há dúvida de que o procedimento da demarcação deve respeitar o princípio constitucional do devido processo legal, segundo o qual 'ninguém será privado da liberdade ou de seus bens sem o devido processo legal' (art. 5, LIV, CF)” SARMENTO, Daniel. Nota Técnica: A PEC 215/00 e as Cláusulas Pétreas. Disponível em $<$ http://noticias.pgr.mpf.mp.br/noticias/noticias-do-site/copy_of_indios-eminorias/portal_factory/copy_of_pdfs/nota-pec-215-final-1-1.pdf > . Acesso em 05.04.2015.

83 Como ocorreu no caso da apelação cível n. ${ }^{\circ}$ 5006496-22.2012.404.7006, TRF4, Desembargadora Federal Marga Inge Barth Tessler, qual foi solicitada a declaração de nulidade da Portaria n. ${ }^{\circ}$ 1.794/2007, editada pelo Ministério da Justiça, que declarou a tradicionalidade da ocupação dos índios Kaigang na área conhecida como Fazenda Passo Liso, no Município de Laranjeiras do Sul, Paraná. A apelação foi negada confirmando a sentença que julgou improcedente o pedido de declaração de nulidade da Portaria. 
nessas terras, sendo que na maioria das vezes não possuem legitimidade no pleito.

Por fim, existem graves problemas na fase de homologação, tendo em vista que a Portaria editada pelo Ministro da Justiça, posteriormente encaminhada para homologação do Presidente da República pode ficar por longo lapso temporal aguardando para ser transformada em um Decreto. ${ }^{84}$ Além disso, o Decreto homologatório também é constantemente alvo de medida judicial.

Somada à previsão constitucional da demarcação da terra prevista no artigo 231 da Constituição, o artigo 64 dos Atos das Disposições Constitucionais Transitórias determinou que a União deveria concluir a demarcação das terras indígenas dentro do prazo de cinco anos contados de sua promulgação, o que não foi feito. O que se pretendia era a finalização dos procedimentos demarcatórios que já estavam em andamento, dando início ainda à demarcação em locais ainda não iniciados.

Infelizmente não foi o que ocorreu na prática. Decorridos 27 anos de promulgada a CFRB muitas terras ainda não se encontram demarcadas pelo Poder Executivo Federal, acarretando enormes prejuízos ao povo indígena, que se encontra em situação de vulnerabilidade.

Hoje em território brasileiro existem conhecidas um total de 544 terras indígenas. Deste total, 426 são terras já demarcadas e devidamente registradas, 14 são terras homologadas pelo Presidente da República mas

\footnotetext{
${ }^{84}$ No dia 20.04.2015 foram publicados decretos homologando a demarcação de mais três terras indígenas, sendo estas: "Terra Indígena (TI) Arara da Volta Grande do Xingu, dos povos Arara e Juruna, no município de Senador José Porfírio (PA); da TI Mapari, do povo Kaixana, nos municípios de Fonte Boa, Japurá e Tonantins (AM); e da TI Setemã, do povo Mura, em Borba e Novo Aripuanã (AM)." Contudo, "há dois anos a presidenta Dilma Rousseff não assinava decretos de homologação de TIs (...) As três áreas não tinham nenhum impedimento legal ou administrativo para avançar no processo de regularização. Nessa mesma situação, há ainda 18 TIs já declaradas que seguem na mesa da presidenta aguardando decretos de homologação e outras 12 que aguardam a assinatura da portaria declaratória do ministro da Justiça, José Eduardo Cardozo”.

Instituto Socioambiental. Após mobilização indígena, Dilma homologa três Terras Indígenas e

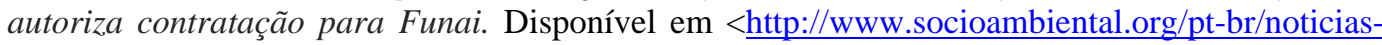
socioambientais/apos-mobilizacao-indigena-dilma-homologa-tres-terras-indigenas-e-autorizacontratacao-para-funai>, acesso em 07.05.2015.
} 
pendentes de registro cartorário, 66 são terras declaradas pelo Ministro da Justiça que aguardam homologação presidencial e 38 são terras delimitadas pelos estudos da Funai que encontram-se em fase de contraditório administrativo ou sob análise do Ministro da Justiça. Atualmente existem 129 em fase de estudos para delimitação de demarcação. ${ }^{85}$

\subsection{Desafios da terra indígena}

Nas palavras do Ministro Celso de Mello:

“a disputa pela posse permanente e pela riqueza das terras tradicionalmente ocupadas pelos índios constitui o núcleo fundamental da questão indígena no Brasil”"86 (grifos meus)

Desse modo podemos depreender que o cerne da questão indígena reside no fato que apesar da ampla proteção e direitos que o texto constitucional confere aos índios brasileiros, suas terras sofreram no passado e ainda são alvo de invasões por parte de seringueiros ${ }^{87}$, garimpeiros $^{88}$, madeireiros, caçadores e de outros grupos da sociedade civil que possuem o interesse de explorar atividades econômicas no local. Tratase de um disputa que recai sobre os direitos da posse de terras tradicionalmente ocupadas.

${ }^{85}$ Funai. Terras Indígenas. Disponível em <http://www.funai.gov.br/index.php/indios-nobrasil/terras-indigenas>. Acesso em 19.05.2015.

${ }^{86}$ STF, RE 183188/MS, Rel. Ministro Celso de Mello, Brasília, 14 fev. 1997.

${ }^{87}$ Em 1912, com o uso industrial da borracha, houve uma explosão na extração da matéria prima na região de floresta amazônica, que contou com a presença de cerca de 160 mil seringueiros. A extração se iniciou em Belém, em seguida se estendeu para o Xingu e Tapajós. O ciclo da borracha deixou um rastro de genocídio, etnocídio e aculturação de diversos povos indígenas da região. LOPES, Nei. História e cultura dos povos indígenas no Brasil. São Paulo: Barsa Planeta, 2009.

88 “A situação agravou-se quando satélites detectaram a existência ali de importantes jazidas de minerais. Uma invasão de garimpeiros na região [terras indígenas Yanomami (Roraíma)] transformou-se em uma verdadeira corrida do ouro no fim dos anos 1980. (...) no auge desse movimento, o número de garimpeiros chegou a ser calculado entre 30 mil e 40 mil, o quíntuplo da população indígena que ali vivia.” Ibid, pp. 89 e 90. 
Como se não bastasse a invasão motivada por fins meramente econômicos, muitos destes territórios foram cortados por ferrovias ou estradas $^{89}$, além de estarem sujeitos à possibilidade de inundação para instalação de usinas hidrelétricas ${ }^{90}$.

O esbulho que vem ocorrendo nas terras indígenas vai totalmente contra a Constituição pois o direito a posse permanente e usufruto exclusivo da terra previstos no art. 231 do texto não vem sendo respeitados por toda a sorte de grupos econômicos. Pode-se dizer ainda que na atualidade fazendeiros e outros membros da sociedade procedem como os primeiros portugueses colonizadores que vieram para o Brasil, invadindo de modo abrupto contra os índios que se recusam a sair de suas terras ${ }^{91}$. Como bem observou o antropólogo Darcy Ribeiro, o que ocorre na prática são fazendas de criação de gado, zonas de exploração agrícola e extrativistas que, por necessitarem de mais áreas para exploração de suas atividades, desrespeitam as terras indígenas, avançando sobre as mesmas.

Narra o antropólogo:

"Os índios Xavante, pacificados em 1946, estão perdendo suas terras para latifundiários que nunca as viram (...) O mesmo está ocorrendo com as tribos vizinhas, como os Karajá e Tapirapé e as do Xingu, cujas terras só não foram ocupadas antes por temor aos ataques dos Xavantes."92

Essa situação acarretou no genocídio e etnocídio de várias comunidades indígenas, não faltando exemplos a serem mencionados. $\mathrm{Na}$ década de 1950 grupos de mercenários foram formados a mando de

\footnotetext{
89 "Nas décadas de 1960 e 1970, as rodovias foram a ponta de lança dos projetos de vários governos com o objetivo de integrar regiões menos densamente povoadas do país. Foram abertas estradas como a Belém-Brasília, a BR-364 (que liga São Paulo ao Acre, passando por Rondônia), a BR-174 (de Manaus a Boa Vista, em Roraima, e à Venezuela), a BR-210, também conhecida como Perimetral Norte (do Amapá até a fronteira com a Colombia, no Amazonas) e a maior dela, a Transamazônica, a mais ambiciosa, construída entre 1969 e 1974. (...) o traçado da Perimetral Norte, por exemplo, atravessava territórios de vários grupos ainda não contatados.” Ibid. pp. 89 e 90.

${ }^{90}$ Como ocorre no caso da usina hidrelétrica de Belo Monte, que está sendo construída na bacia do Rio Xingu e a hidrelétrica São Luiz do Tapajós.

${ }^{91}$ TOURINHO NETO, Op. cit., p. 35.

${ }^{92}$ RIBEIRO, Op. cit., pp. 102-107.
} 
exploradores com a incumbência de eliminar comunidades indígenas que gerassem empecilho aos seus interesses. Isto porque índios que eram possuidores da terra, mas que não serviam como mão de obra para a atividade dos exploradores, consistiam em entrave ao desenvolvimento econômico da região e por isso a utilização da força se tornava a solução para os mandatários. Sendo assim, as mais diversas formas de violência foram empregadas contra os povos indígenas.

\begin{abstract}
Alguns relatos denotam que:
"Alimentos misturados a arsênico, brinquedos e roupas contaminados com o vírus da gripe, sarampo e varíola lançados de avião sobre as aldeias: eram muitos os expedientes usados por fazendeiros, madeireiros e colonos para (...) expulsar os indígenas de terras por eles cobiçadas no Mato Grosso, na época da fronteira agrícola que se abria no país." 93
\end{abstract}

Em 1963 tivemos o episódio que ficou conhecido como Massacre do Paralelo 11. O fato se deu em regiões de jazidas, onde de um lado estavam seringueiros aliados a empresas de mineração e de outro índios Cinta$\operatorname{Larga}^{94}$.

O desafio de se manter a posse da terra é tamanha que, quando o esbulho das terras indígenas não é perpetrado por civis, o Estado se encarregada de fazê-lo. Isto porque a administração pública, ao invés de proteger corretamente as áreas, constrói rodovias, ferrovias ${ }^{95} \mathrm{e}$ hidrelétricas $^{96}$, vende terras adjacentes para iniciativa privada, contesta os relatórios de demarcação das terras, sendo resistente na concessão de títulos de posse aos índios, tendendo a apoiar os interesses de latifundiários.

\footnotetext{
${ }^{93}$ LOPES, Op. cit., p. 90.

${ }^{94}$ No caso um grupo de capangas invadiram e mataram com tiros e golpes de facão uma aldeia inteira de Cinta-Larga. Esse é um dos poucos casos de extermínio que teve grande repercussão, pois, posteriormente se descobriu que servidores do próprio órgão de proteção indígena (Serviço de Proteção ao Índio) estavam envolvidos nos atos perpetrados contra os índios daquela etnia em favor dos garimpeiros. O fato levou à extinção do SPI que veio a ser substituído pela FUNAI. LOPES, Op. cit., p. 89.

${ }^{95}$ Exemplos vide rodapé 91.

${ }^{96}$ Exemplos vide rodapé 92.
} 
O desrespeito aos direitos indígenas e às normas legais é tão grande que, vale lembrar o caso dos índios Kadiwéu, habitantes do Estado do Mato Grosso. Suas terras foram devidamente demarcadas através de decreto estadual em 1931, seguindo o procedimento vigente à época. Passados alguns anos, a assembleia legislativa estadual aprovou uma lei tornando as terras já demarcadas em devolutas, suprimindo assim o veto do executivo. Nesse caso, apesar de ocorrido em 1958, sendo portanto anterior à Constituição de 1988, já havia sido constitucionalmente reconhecido aos índios sua posse permanente sobre as terras que tradicionalmente habitavam. A situação somente foi revertida quando a demanda foi levada ao Supremo Tribunal Federal onde foi reconhecido que o Estado do Mato Grosso não poderia ter como devolutas tais terras pois já eram possuídas a título legítimo ${ }^{97}$. Em casos como estes, a atuação do Poder Judiciário se faz fundamental para reverter a situação de injustiça.

Não seria equivocado dizer que as normas constitucionais e infraconstitucionais relativas aos direitos da terra indígena não passam de princípios, como observou Darcy Ribeiro, para o qual seriam apenas “conjuntos de princípios cuja aplicação é simplesmente desejável" ${ }^{\text {98 }}$. O que ocorre na realidade indígena destoa totalmente da legislação brasileira, pois a posse indígena é precariamente mantida uma vez que os anseios da iniciativa privada e de integrantes do governo, que atuam afastando a aplicação da norma, são mais poderosos do que os anseios indígenas. Assim bem entende o autor:

"Estamos, como se vê, diante de um processo ecológico de sucessão, mediante o qual uma população original está sendo substituída por outra, dotada de recursos mais eficientes de contrôle e exploração da natureza e, sobretudo, de fôrça para impor sua expansão." 99

\footnotetext{
${ }^{97}$ RIBEIRO, Op. cit., pp. 108-112.

${ }^{98}$ Ibid. p. 112.

${ }^{99}$ RIBEIRO, Op. cit., p. 113.
} 
Estamos portanto frente a um problema que se funda na dificuldade em se tornar exequível o conteúdo normativo do art. 231 da CRFB. De acordo com Paulo Nader, quando estudamos a norma jurídica devemos considerar alguns de seus aspectos: vigência, efetividade, eficácia e legitimidade. ${ }^{100}$ A norma do art. 231 da CRFB, que reconhece os direitos originários aos índios brasileiros sobre as terras que tradicionalmente ocupam, encontra problemas nos campos da efetividade e da eficácia. Para o autor tais conceitos possuem elementos que não podem ser confundidos, pois enquanto a efetividade "consiste no fato de a norma jurídica ser observada tanto por seus destinatários quanto pelos aplicadores do Direito”101 além de simbolizar “a aproximação, tão intima quanto possível, entre o dever ser normativo e o ser da realidade social”102, a eficácia diz respeito ao alcance da norma no campo social, a saber, "significa que a norma jurídica, produz, realmente, os efeitos sociais planejados". ${ }^{103}$

Como observado, a norma do art. 231 não é plenamente cumprida por todos os seus destinatários sendo pouco observada pelos que são responsáveis pela sua aplicação. Assim sendo, se a mesma não é corretamente observada, não há como produzir os efeitos sociais desejados no plano prático.

Nesse sentido, Paulo Nader assevera:

“(...) para que a eficácia se manifeste, indispensável é que seja observada socialmente”. 104

Com efeito, para que os índios usufruam plenamente do direito da posse permanente as terras que tradicionalmente ocupam e garantam sua existência de acordo com seus usos, costumes e tradições é fundamental

\footnotetext{
100 A legitimidade se funda "no exame da fonte de onde emana a norma”. Nader, Paulo. Introdução ao estudo do direito. Rio de Janeiro: Forense, 2010, p. 95.

${ }^{101}$ NADER, Paulo. Introdução ao estudo do direito. Rio de Janeiro: Forense, 2010, p. 94.

102 BARROSO, Luís Roberto. Direito Constitucional e a efetividade de suas normas. Rio de Janeiro: Editora Renovar, 2009, p. 85.

103 NADER, Op. cit., p. 94.

104 NADER, Op. cit., p. 95.
} 
que a norma do art. 231 da CRFB alcance a máxima efetividade, sendo consequentemente, eficaz.

\subsection{O Poder Legislativo frente às terras indígenas}

É inegável o avanço que houve na luta indígena com a promulgação da Constituição da República Federativa do Brasil de 1988. O texto constitucional é bastante favorável à questão dos direitos dos índios, já confirmada por algumas lideranças. ${ }^{105}$

Houve uma grande articulação entre indígenas e ONG's para que os direitos originários dos índios sobre as terras que tradicionalmente ocupam fossem reconhecidos pela Assembleia Constituinte e inseridos no texto constitucional. ${ }^{106}$ Apesar de estarmos diante de uma norma garantidora de direitos, há dificuldade para a manutenção da posse permanente sobre a terra pelos índios.

Mesmo diante de todo o avanço constitucional, como se já não bastassem os entraves administrativos existentes no procedimento demarcatório, existe uma tendência do Poder Legislativo em mitigar ou

\footnotetext{
${ }^{105}$ GARCIA, Pedro. O movimento indígena e a demarcação das terras. Brasília: Funai, 2002,p. 39.

${ }^{106}$ Nesse sentido "Nós, isto é, eu e os colegas, diretores da nova organização recém criada, com o apoio de algumas ONG's, entre elas o CIMI - Conselho Indigenista Missionário, tivemos a oportunidade de participar e até ajudar na coordenação das grandes mobilizações Pró-Constituinte, tanto em Brasília e nas bases, isto é, nas comunidades ou aldeias indígenas de nossa área. (...) A Constituinte era uma tarefa muito importante e difícil, pois estavam em jogo os destinos de todo o povo brasileiro, inclusive dos povos indígenas, que não tinham então nenhum representante no Congresso Nacional. Mas graças às campanhas internacionais e à sensibilidade de alguns congressistas e o grande esforço das lideranças indígenas em percorrer os gabinetes dos deputados federais e senadores para defender seus direitos históricos, finalmente, em outubro de 1988, houve a promulgação da Constituição favorável à questão indígena, pois a Constituição reconhecia e reconhece as organizações sociais e formas de vida diferenciadas (cultura, tradição, usos e costumes) dos povos indígenas” Pedro Garcia. O movimento indígena e a demarcação das terras, p. 39.
}

No mesmo sentido "A formatação dessas conquistas resultou de um longo processo de negociação entre setores anti-indigenistas e figuras como o jurista Dalmo Dallari e o governador Mário Covas durante a Constituinte. O critério final, que define as terras de direito indígena como aquelas "tradicionalmente ocupadas", é considerado um grande avanço por aqueles que defendem a causa indígena.” FURUIE, Vinicius. Índios encontram dificuldade em demarcar terras. Disponível em $<$ http://www.conjur.com.br/2007-mai-20/indios_encontram_dificuldade_demarcar_terra $>$. Acesso em 11.05.2015. 
tentar retirar os direitos constitucionalmente previstos aos índios. Prova disso é que hoje no Congresso Nacional tramitam diversas propostas de emenda à constituição ${ }^{107}$, que visam mitigar os direitos originários dos índios sobre as terras ocupadas e transferir a competência demarcatória do Poder Executivo para o Poder Legislativo, afrouxando ainda mais um procedimento demarcatório que na prática já não tem se mostrado tão eficaz.

Nesse sentindo, observou Dalmo de Abreu Dallari:

"Ninguém pode ter dúvida de que os direitos dos índios são direitos humanos. Infelizmente, ainda há muita resistência a efetivação desse direito. O que se tem visto é uma pressão muito forte, partida do agronegócio, no sentido de dificultar a sua efetivação. No Congresso têm sido apresentadas propostas que visam claramente à redução dos direitos indígenas, como transferir a competência da demarcação das terras indígenas para o Legislativo". ${ }^{108}$

A proposta mais preocupante é a trazida pela PEC n. ${ }^{\circ} 215$. Ela visa acrescentar o inciso XVIII ao art. 49, modificar o $\S 4^{\circ}$ do art. 231 e acrescentar o $\S 8^{\circ}$ ao art. 231 da Constituição Federal, dispondo que é de competência exclusiva do Congresso Nacional a aprovação de demarcação das terras tradicionalmente ocupadas pelos índios e a ratificação das demarcações já homologadas pelo Presidente da República. Passando a ter a seguinte redação:

“Art. 49. É da competência exclusiva do Congresso Nacional:

(...)

XVIII- aprovar a demarcação de terras tradicionalmente ocupadas pelos índios e ratificar as demarcações já homologadas.

(...)

Art. 231 (...)

$\S 4^{\circ}$. As terras de que trata este artigo, após a respectiva demarcação aprovada ou ratificada pelo Congresso Nacional, são inalienáveis e indisponíveis e os direitos sobre elas imprescritíveis.

(...)

\footnotetext{
${ }^{107}$ PEC n. ${ }^{0}$ 215/2000 é de autoria do Deputado Federal Almir Morais Sá. PEC’s n. ${ }^{\circ}$ 579/2002, n. ${ }^{\circ}$ 275/2004, n. ${ }^{\circ} 319 / 2004$, n. ${ }^{\circ}$ 37/2007 e n. ${ }^{\circ}$ 117/2007 foram criadas, respectivamente, pelos deputados federais, Ricarte de Freitas (PSDB/MT), Lindberg Farias (PT/RJ), Zequinha Marinho (PSC/PA), Eliene Lima (PP/MT) e Edio Lopes (PMDB/RR).

${ }^{108}$ Comissão Pró-Índio de São Paulo. Cenaìrio nacional è̀ de paralisaçapo das demarcaçopes de terras indiigenas. Disponível em

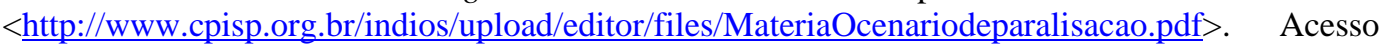
em 11.05.2015.
} 
$\S 8^{\circ}$. Os critérios e procedimentos de demarcação das Áreas indígenas deverão ser regulamentados em lei.”

Segundo os defensores da referida PEC, submeter ao crivo do Congresso Nacional a demarcação das terras, evitaria conflitos federativos e daria maior segurança jurídica às demarcações. ${ }^{109}$ Mas o que tem sido visto é que esses defensores são integrantes da bancada ruralista do Congresso Nacional ou possuem vínculos com setores do agronegócio e da mineração. O objeto da proposta visaria então, pura e simplesmente, mitigar a posse permanente do índio à terra, facilitando assim a posse dessa mesma terra por setores da economia interessados em sua exploração.

Resta claro portanto o quão absurda é essa proposta. Ela colocaria as terras já devidamente homologadas e com registros nos devidos cartórios, sob ratificação do Congresso Nacional. Sendo assim, todas as terras que passaram longos anos desde 1988 sob o procedimento administrativo de demarcação, estariam agora sujeitas a mais um procedimento, o da ratificação. Trata-se portanto de uma ratificação permeada por interesses meramente políticos ${ }^{110}$.

Muitos autores ${ }^{111}$ e autoridades públicas ${ }^{112}$ já se pronunciaram acerca da inconstitucionalidade da PEC n. ${ }^{\circ}$ 215, pois o art. $60, \S 4^{\circ}$, IV da CRFB veda reformas constitucionais tendentes a abolir direitos e garantias

\footnotetext{
${ }^{109}$ SARMENTO, Op. cit., p. 2.

${ }^{110}$ Ibid.

${ }^{111}$ CUNHA, Manuela Carneiro; SARMENTO Daniel.

${ }^{112}$ Ministro da Justiça José Eduardo Cardozo.

Ministério da Justiça. Ministro considera inconstitucional PEC da demarcação de terras indígenas. Disponível em $<\underline{h t t p: / / w w w . j u s t i c a . g o v . b r / n o t i c i a s / m i n i s t r o-c o n s i d e r a-i n c o n s t i t u c i o n a l-~}$ pec-da-demarcacao-de-terras-indigenas $>$, acesso em 11.05.2015.
}

Além de Jader Barbalho (PA), Romero Jucá (RR), Eunício Oliveira (CE), Aécio Neves (MG), José Serra (SP), Aloysio Nunes (SP), Álvaro Dias (PR), Gleisi Hoffmann (PR), Walter Pinheiro (BA), Humberto Costa (PE), Jorge Viana (AC) e José Pimentel (CE). VALENTE, Rubens. Senadores assinam documento contra PEC que muda demarcação de terras. Folha de São Paulo, Brasília, 27.05.2015, disponível em <http://www1.folha.uol.com.br/poder/2015/05/1634401-senadoresassinam-documento-contra-pec-que-muda-demarcacao-de-terras.shtml $>$. 
individuais. Desse modo, ao falarmos dos direitos dos índios previstos no art. 231 da CRFB, estaríamos diante de um direito e garantia fundamental, logo, de uma clausula pétrea. Nesse sentido sustenta Daniel Sarmento:

"O art. 60, $\S 4^{\circ}$, inciso IV, da Constituição, veda reformas constitucionais tendentes a abolir os "direitos e garantias individuais". A doutrina amplamente majoritária vem ressaltando que os direitos salvaguardados pelo preceito em questão não são apenas as liberdades públicas tradicionais - os típicos direitos de $1^{\text {a }}$ geração ou dimensão -, mas todos os direitos fundamentais, inclusive aqueles localizados fora do catálogo constitucional de direitos (arts. $5^{\circ}$ a 17).,"113

E continua:

“(...) subordinar um direito fundamental às escolhas políticas das maiorias parlamentares é comprometer a sua essência (...) os direitos fundamentais, pela sua própria natureza, são limites impostos às maiorias. Na conhecida expressão de Ronald Dworkin, os direitos são 'trunfos', que prevalecem sobre preferências majoritárias ou meros cálculos de utilidade social. Os direitos fundamentais têm, por isso, uma dimensão contramajoritária, pois a sua garantia não depende das preferências das maiorias políticas ou sociais de ocasião."114

Condicionar a demarcação ao procedimento legislativo implica em inserir um conteúdo político nas decisões de demarcação, que atualmente, se reveste apenas em uma decisão técnica do Chefe do Poder Executivo Federal. ${ }^{115}$ A alteração proposta implica em deixar que o processo de demarcação possa ser influenciado por interesses políticos de empresas do setor privado.

É notório que os índios não possuem representação no Congresso Nacional, e por isso não teriam força para lutar contra o conteúdo político das decisões parlamentares, tampouco possuem a influência econômica que as empresas privadas, maiores interessadas nas terras tradicionalmente ocupadas, exercem no Congresso. Isto posto, passar a tarefa da demarcação para as mãos do Poder Legislativo é de um lado viabilizar os interesses da iniciativa privada e do outro diminuir drasticamente a posse permanente da

\footnotetext{
${ }^{113}$ SARMENTO, Op. cit., p. 13

${ }^{114}$ Ibid. p. 14

${ }^{115}$ Ibid. p. 16
} 
terra pelos índios, destruindo a possibilidade de preservação de todo seu costume e tradição. Nesse sentido Daniel Sarmento:

\begin{abstract}
“Os índios brasileiros constituem uma minoria estigmatizada e vítima de preconceito, que tem poucas armas na luta política e não conta atualmente com nenhum representante no Congresso. E o Parlamento Federal, com todo o respeito que a instituição merece, é uma instância profundamente infiltrada pelo poder econômico, onde se faz presente, com enorme força e poder de barganha, uma ampla bancada ruralista, adversária histórica, ferrenha e implacável dos direitos dos índios."
\end{abstract}

No mesmo sentido, observa Manuela Carneiro da Cunha ${ }^{117}$ :

"Estamos em um cenário de cobiça às terras que estão fora do mercado, as áreas de conservação e as terras indígenas. O governo, que está refém de uma poderosa bancada no Congresso, que alia ruralistas e evangélicos, sacrifica então o que lhe parece ter importância secundária. É uma questão de prioridades quando deveria ser uma questão de princípios."

Estamos diante portanto de uma triste realidade para todo o povo indígena brasileiro que há séculos luta por suas terras diariamente. É latente a dificuldade existente no Brasil para se garantir a posse permanente da terra para os índios, pois, como já observado, existem obstáculos de diferentes ordens. Em primeiro lugar, dificuldades geradas por membros da sociedade civil que esbulham as terras indígenas. Em seguida obstáculos advindos do Poder Executivo que pouco demarca e pouco protege as terras indígenas e por fim, como visto neste capítulo, existem obstáculos colocados pelo Poder Legislativo, que quer de vez retirar do texto da norma direitos e garantias fundamentais que asseguram a terra aos povos indígenas.

Diante de toda esse processo político, que vem trazendo muitas propostas que ameaçam os direitos dos índios sobre as terras que

\footnotetext{
${ }^{116}$ SARMENTO, Op. cit., p. 17.

${ }^{117}$ Antropoìloga e professora titular aposentada da Universidade de Sabo Paulo.

${ }^{118}$ Comissão Pró-Índio de São Paulo. Cenaìrio nacional è̀ de paralisaçaPo das demarcaçopes de terras indiìgenas. Disponível em $<$ http://www.cpisp.org.br/indios/upload/editor/files/MateriaOcenariodeparalisacao.pdf $>$. Acesso em 11.05.2015.
} 
tradicionalmente ocupam para assim viabilizar a posse e propriedade das áreas por não índios, o Poder Judiciário, vem cada vez mais sendo demandado por índios que buscam tutela sobre seus direitos à posse permanente sobre as terras tradicionais (fazendo valer $\mathrm{o}$ texto constitucional) e por não índios que visam impedir ou retardar o andamento e conclusão da demarcação dessas terras. 


\section{CAPÍTULO 3. POSICIONAMENTO DOS TRIBUNAIS}

Analisados alguns dos obstáculos que os Poderes Executivo e Legislativo, além de setores da sociedade civil inserem no procedimento demarcatório e na manutenção da posse permanente das terras tradicionalmente ocupadas pelos índios, este capítulo se propõe analisar a dimensão da questão da posse da terra indígena perante o Poder Judiciário. A análise do Poder Judiciário na questão se dará através do estudo de entendimentos firmados pelo Supremo Tribunal Federal, sobretudo pelo estudo do caso referência Raposa Serra do Sol.

\subsection{O Poder judiciário e as terras indígenas}

Conforme já visto no capítulo II, a demarcação das terras indígenas deveria se dar através da via administrativa, em acordo com a Lei Federal n. ${ }^{\circ}$ 6.001/1973, regulada pelo Decreto n. ${ }^{0} 1.775 / 1996$, contudo na prática a demarcação tem sido frequentemente levada para o Poder Judiciário.

De acordo com o disposto no art. 109, XI, da CFRB, compete à Justiça Federal dirimir conflitos que envolvam disputas sobre conflitos indígenas. Sendo assim, a Justiça Federal vem sendo frequentemente acionada durante a tramitação do procedimento administrativo demarcatório como forma de se inviabilizar a conclusão da demarcação. Muitos interessados em que as terras indígenas não sejam demarcadas recorrem a esse expediente para obter decisões liminares favoráveis a suspensão da demarcação e assim retardar o procedimento até que seja dada a decisão de mérito.

Observam Luiz Henrique Eloy ${ }^{119}$ e Lilian Tenório ${ }^{120}$ que grande quantidade de conflitos envolvendo as terras indígenas estão sob a jurisdição da Justiça Federal de Mato Grosso do Sul:

\footnotetext{
${ }^{119}$ Luiz Henrique Eloy Amado é Terena da Aldeia Ipegue, assessor jurídico do Conselho Indigenista Missionário (CIMI) no estado de Mato Grosso do Sul e Mestre em Desenvolvimento Local pela Universidade Católica Dom Bosco.
} 
“A judicialização fica evidente a partir da listagem dos processos levantados durante pesquisa, demonstrando o altíssimo número de ações judiciais. Neste levantamento é possível averiguar as inúmeras ações judiciais em trâmite perante a Justiça Federal de Mato Grosso do Sul, bem como os recursos interpostos perante o Tribunal Regional Federal da 3a Região que é a segunda instância de jurisdição."121

De acordo com levantamento realizado, tramitam na Justiça Federal do estado trezentos e oitenta e oito processos judiciais que versam sobre demarcação de terras indígenas e conflitos possessórios. ${ }^{122}$

No entanto, a judicialização da demarcação não fica restrita aos tribunais federais, pois alguns desses casos tem chegado ao Supremo Tribunal Federal, a quem cabe a guarda da Constituição Federal. Trata-se de uma jurisdição de mais difícil acesso por particulares, considerando que sua competência está limitada às hipóteses previstas nos incisos I, II e III do art. 102 da CRFB. A despeito disso os autores verificaram a existência de mais treze ações nessa instância, fora os conflitos oriundos de outros estados da federação. ${ }^{123}$

A possibilidade de provocar o STF decorre da aplicação da alínea $f$, inciso I do art. 102 da CRFB, in verbis:

“Art. 102. Compete ao Supremo Tribunal Federal, precipuamente, a guarda da Constituição, cabendo-lhe:

I - processar e julgar, originariamente:

$(\ldots)$

\footnotetext{
${ }^{120}$ Lilian Raquel Ricci Tenório é Mestranda em Antropologia pela Universidade Federal de Mato Grosso do Sul, bacharel em Direito pela Universidade Católica Dom Bosco e em Ciências Sociais pela Universidade Federal de Mato Grosso do Sul.

${ }^{121}$ AMADO, Luiz Henrique Eloy; TENÓRIO, Lilian Raquel Ricci. A luta do povo Terena por seus territórios tradicionais: Reflexões sobre demarcação, judicialização e mesa de diálogo. Disponível em <http://www.seminarioamericaplatina.com/restrito/trabalho/Luiz-Henrique-EloyAmado-301014-2335-artigo_eloy\%20e\%20lilian_versao\%20final.pdf> $\quad$ p. $7 . \quad$ Acesso em 28.05.2015.

${ }^{122}$ Ibid.

${ }^{123}$ Ibid., p. 8.
} 
f) as causas e os conflitos entre a União e os Estados, a União e o Distrito Federal, ou entre uns e outros, inclusive as respectivas entidades da administração indireta;"

Amparados por essa norma, estados da federação, como o Estado de Mato Grosso do Sul, ingressam como parte, fazendo com que o processo seja deslocado da Justiça Federal para o Supremo Tribunal Federal, já que no conflito também estão envolvidas como parte adversa a União e a Funai. ${ }^{124}$ Com o deslocamento do processo para o STF, o tempo para se obter uma decisão terminativa é ainda mais longo, deixando comunidades indígenas sem segurança quanto a manutenção da posse sobre suas terras.

\subsection{O Supremo Tribunal Federal e as terras indígenas}

A pesquisa realizada na jurisprudência da Corte, quanto ao litígio que envolve terras indígenas, em sua maioria são muito semelhantes, têm a mesma natureza e possuem o seguinte objeto:

(i) ações originárias que visam a nulidade de títulos da propriedade rural concedidos a não índios, situados em terras indígenas; ${ }^{125}$

(ii) mandados de segurança contra ato do Presidente da República que homologou terras indígenas tradicionalmente habitadas $\mathrm{e} ; ;^{126}$

(iii) recurso extraordinário ou ordinário oriundo de ações que discutem a posse da terra entre índios e não índios. ${ }^{127}$

O STF considera os artigos 231 e 232 da CRFB pilares do estatuto jurídico da causa indígena. A Corte reconhece a importância e a fundamental aplicação do art. 231 da Constituição Federal, entendendo que

\footnotetext{
${ }^{124}$ Ibid.

${ }^{125}$ Exemplos: Ação Cível Originária n. ${ }^{\circ} 312$ (BA) e Ação Cível Originária n. 323 (MG).

${ }^{126}$ Exemplos: Mandado de Segurança n. 21892 (MS) e Mandado de Segurança n. ${ }^{\circ} 25483$ (DF).

${ }^{127}$ Exemplos: Recurso Extraordinário n. ${ }^{\circ} 803462$ (MS), Recurso Ordinário n. 29542 (DF), Recurso Ordinário n. 29087 (DF).
} 
a demarcação de terras indígenas é um ato meramente declaratório e não constitutivo, porque os direitos dos índios sobre as terras que tradicionalmente ocupam são originários e anteriores a qualquer ato da administração pública. O STF reconhece o direito a posse permanente dos índios sobre terras que tradicionalmente ocupam e esta "independe da conclusão do procedimento administrativo de demarcação na medida em que a tutela dos índios decorre, desde sempre, diretamente do texto constitucional."128

Nesse sentido foi assim que entendeu o Ministro Luiz Fux, quando aplicou o $\S 6^{\circ}$ do art. 231, que versa que são nulos os efeitos jurídicos da ocupação e posse de não índios em terras tradicionalmente ocupadas por índios:

“AÇÃO ORIGINÁRIA. AÇÃO DE NULIDADE DE TÍTULOS DE PROPRIEDADE SOBRE IMÓVEIS RURAIS SITUADOS NO SUL DA BAHIA EM RESERVA INDÍGENA (...) Demarcação da área sub judice ocorrida em 1938 desacompanhada de homologação da demarcação de terras indígenas. Incerteza oriunda da ausência de homologação da demarcação de terras indígenas relegando a comunidade a uma situação frágil e a um ambiente de violência e medo na região (...). Homologação ausente, da demarcação administrativa realizada em 1938, não inibe o reconhecimento da existência de reserva indígena no local, originando a impossibilidade de se ter por válidos atos jurídicos formados por particulares com o Estado da Bahia." ${ }^{29}$

Em casos observados o STF atuou de modo a suprir a omissão do Poder Executivo, que deixou de editar o decreto de homologação das terras tradicionalmente habitadas por índios. Sem a homologação, não é possível avançar para a etapa de registro das terras no cartório imobiliário e na Secretaria do Patrimônio da União do Ministério da Fazenda (cf. previsto no art. $6^{\circ}$ do Decreto n. ${ }^{\circ}$ 1.775/1996). Como bem observado pela Ministra

\footnotetext{
128 STF, ACO n. 312 (BA), Rel. Min. Eros Grau, Brasília, 02 maio 2012.

129 "Esta açaßo foi ajuizada pela Fundaça๖o Nacional do Iìndio (Funai), em $1^{\circ} .7 .1982$, com o objetivo de ver declarada a nulidade de tiìtulos de propriedade e registros imobiliaìrios referentes a imoìveis que estariam situados em terras indiìgenas. Tais imoìveis estariam localizados, segundo a Autora, nos municiìpios baianos de Conquista, Itambeì, Itapetinga, Canavieiras, Itabuna, Pau Brasil e Itaju do Colônia.” STF, ACO n. ${ }^{\circ} 312$ (BA), Voto Ministro Luiz Fux, Brasília, 21 março 2013.
} 
Carmem Lúcia em seu voto, a omissão do Poder Executivo na demarcação acarreta em conseqüências desastrosas aos índios:

“(...) foi a União que deixou, em mais de setenta anos, de homologar a demarcação da reserva, deixando em desvalia os índios que deveria proteger e fazendo com que passassem a perambular à cata de um território devidamente afirmado como sendo seu habitat e causando ou permitindo, pelo menos, os estragos culturais, sociais e econômicos com que eles passaram a conviver desde então; foi este estado de coisas que trouxe a Brasília, em 1997, o índio Galdino, ${ }_{131}$ dos líderes da tribo, que acabou martirizado pela ação criminosa de civis." ${ }^{\prime 30}$ Muito bem observado pela Ministra é histórica a omissão do Estado e a violência urbana com agravamento das vulnerabilidades atingem também os indígenas.

Contudo, a posição do STF no assunto deve ser analisada com muita cautela, pois hoje existem dois requisitos que vem sendo aplicados pela Corte para se configurar a existência de terra indígena: (i) a temporalidade da ocupação (requisito do marco temporal) ${ }^{132}$ e; (ii) a tradicionalidade da ocupação (prevista no art. 231 da CRFB).

Embora o STF atue muitas vezes suprimindo a omissão do Poder Executivo, não é possível afirmar que há no STF uma jurisprudência no sentido pleno da proteção dos direitos indígenas, uma vez que, pelo que foi observado em alguns acórdãos, as decisões dos Ministros têm sido devidamente fundamentadas com o artigo 231 da CRFB (e legislação infraconstitucional). Além é claro do respaldo nas provas fornecidas pelas partes, principalmente laudos da Funai, elaborados por antropólogos, que

\footnotetext{
${ }^{130}$ STF, ACO n. 312 (BA), Voto Ministra Carmem Lúcia, Brasília, 21 março 2013.

${ }^{131}$ Em 1997, o índio Gaudino foi à Brasilia com o objetivo de buscar apoio para as reivindicações da sua comunidade indígena Pataxó Hã-Hã-Hãe que habita a Terra Indígena Caramuru Catarina Paraguaçu, objeto de controvérsia no acórdão debatido pela Ministra Carmem Lúcia.

132 Foi observado que nos acórdãos não há um consenso quanto a natureza do marco temporal, ora é denominado teoria, requisito ou pressuposto, embora possa também ser considerado como um fundamento, considero para o estudo, marco temporal como requisito.
} 
descrevem existência ou não de ocupação tradicional de terras por populações indígenas. ${ }^{133}$

Como se verá a seguir, o requisito do marco temporal constitui um obstáculo aos direitos de comunidades indígenas, inviabilizando a posse permanente da terra por grupos indígenas sobre as terras que foram tradicionalmente habitadas por seus ancestrais.

\subsubsection{Marco temporal e tradicionalidade da ocupação como requisitos de terra indígena e seus efeitos no processo judicial}

O julgamento do caso referência Raposa Serra do Sol explicita uma preocupante tendência que vem se consolidando na Corte. Trata-se do requisito do marco temporal para configuração da ocupação tradicional dos índios sobre a terra reivindicada.

De acordo com esse requisito, a Constituição Federal de 1988 só garantiria aos índios a posse permanente das terras que eles estivessem ocupando no dia da no dia 5 de outubro de $1988 .{ }^{134}$ Desse modo, para comprovar que se trata de uma terra tradicionalmente habitada, as comunidades indígenas devem provar que estavam vivendo no local na data da promulgação da Constituição Federal. Nas palavras do Ministro Carlos Ayres Britto:

“O CONTEÚDO POSITIVO DO ATO DE DEMARCAÇÃO DAS TERRAS INDÍGENAS. 11.1. O marco temporal de ocupação. A Constituição Federal trabalhou com data certa — a data da promulgação dela própria (5 de outubro de 1988) - como insubstituível referencial para o dado da ocupação de um determinado espaço geográfico por essa ou aquela etnia aborígene; ou seja, para o reconhecimento, aos índios, dos direitos originários sobre as terras que tradicionalmente ocupam. 11.2. O marco da tradicionalidade da ocupação. É preciso que esse estar coletivamente situado em certo espaço fundiário também

\footnotetext{
${ }^{133}$ Exemplos: Ação Cível Originária n. 312 (BA), Mandado de Segurança n. ${ }^{\circ} 25483$ (DF) e Mandado de Segurança n. $^{\circ} 21892$ (MS) foram julgados favoráveis aos interesses indígenas. Já o Recurso Ordinário n. ${ }^{\circ} 29542$ (DF) e Recurso Ordinário n. 29087 (DF), foram favoráveis aos latifundiários.

${ }^{134}$ Data da promulgação da Constituição Federal de 1988.
} 
ostente o caráter da perdurabilidade, no sentido anímico e psíquico de continuidade etnográfica."

Na tutela dos direitos dos indígenas esse requisito não abraça as comunidades indígenas que teriam sido expulsas de suas terras e por isso não estariam ocupando-as em 5 de outubro de 1988. A Corte em razão deste perverso efeito da interpretação do referido requisito, criou a figura do chamado "renitente esbulho", uma exceção à regra do marco temporal. Como explicitou o Ministro Carlos Ayres Britto:

\begin{abstract}
“A tradicionalidade da posse nativa, no entanto, não se perde onde, ao tempo da promulgação da Lei Maior de 1988, a reocupação apenas não ocorreu por efeito de renitente esbulho por parte de não-índios. Caso das "fazendas" situadas na Terra Indígena Raposa Serra do Sol, cuja ocupação não arrefeceu nos índios sua capacidade de resistência e de afirmação da sua peculiar presença em todo o complexo geográfico da "Raposa Serra do Sol”,"136
\end{abstract}

Se grupos indígenas expulsos de suas terras que reivindicam a posse de uma suposta terra tradicionalmente ocupada conseguirem comprovar que foram alvo de renitente esbulho será considerada a exceção à regra do marco temporal para garantir a posse permanente da terra. Ainda no contexto do referido agravo, e acordo com o Ministro Teori Zavascki, para configuração de um renitente esbulho deve ser verificada a existência de um conflito possessório na data da promulgação da Constituição Federal. Nesse sentido:

"Há de haver, para configuração de esbulho, situação de efetivo conflito possessório que, mesmo iniciado no passado, ainda persista até o marco demarcatório temporal atual (vale dizer, a data da promulgação da Constituição de 1988), conflito que se materializa por circunstâncias de fato ou, pelo menos, por uma controvérsia possessória judicializada."137

Logo, para fins de comprovação de renitente esbulho basta haver notícia da existência de circunstancias de fato ou pela existência de

\footnotetext{
${ }^{135}$ Plenário STF, Pet. 3.388 (RR), Rel. Ministro Carlos Ayres Britto, Plenário, Brasília, 19 mar 2009.

${ }^{136}$ Ibid.

${ }^{137}$ STF, Agravo no Recurso Extraordinário n. 803462 (MS), Rel. Ministro Teori Zavascki, Brasília, 11 fev 2015.
} 
controvérsia judicial possessória. Entretanto, ocorre que nem diante de renitente esbulho seria possível fazer justiça à todas as populações tradicionais que foram expulsas de suas terras antes de 5 de outubro de 1988. Isto porque alguns grupos indígenas não conseguiram afirmar sua presença em suas terras, montando uma resistência, como conseguiram os grupos da terra indígena Raposa Serra do Sol, narrado anteriormente no voto do Ministro Ayres Britto. É o caso, por exemplo, do grupo indígena Terena, onde o STF, julgando o processo em 2015, não identificou o animo da reinvindicação da posse. De acordo com a Corte, quando o grupo foi expulso de suas terras na década de 1950, muitos índios foram para outras regiões e alguns permaneceram no local trabalhando em fazendas da região. Mas não se configurou disputa possessória, assim:

“(...) sendo incontroverso que as última ocupações indígenas na Fazenda Santa Bárbara ocorreram em 1953 e não se constatando, nas décadas seguintes, situação de disputa possessória, fática ou judicializada, ou de outra especie de inconformismo que pudesse caracterizar a presença de não índios como efetivo 'esbulho renitente', a conclusão que se impõe é a de que indispensável requisito do marco temporal da ocupação indígena, fixado por esta Corte no julgamento da Pet 3.388 não foi cumprido no presente caso."138

De acordo com Deborah Duprat ${ }^{139}$, “exigir a posse contínua e permanente, por toda a vida, dessas comunidades, num determinado território, é desconhecer o processo civilizatório e desenvolvimentista que foi empurrando-as para as margens [do território nacional]”, ${ }^{140}$ além de desconhecer a cultura indígena. Mas o STF entende que “o objetivo principal dessa delimitação foi procurar dar fim a disputadas infindáveis sobre terras, entre índios e fazendeiros, muitas das quais, como sabemos,

\footnotetext{
${ }^{138}$ Ibid.

${ }^{139}$ Vice Procuradora Geral da Repuiblica e coordenadora da $6^{a}$ Câmara de Coordenação e Revisão do MPF, que trata de assuntos relativos aos povos indiìgenas e outras minorias eìtnicas.

${ }^{140}$ SOUZA, Oswaldo Braga de. Decisões recentes ameaçam direitos territoriais indígenas $e$ abrem polêmica no STF. Disponível em <http://www.socioambiental.org/pt-br/noticiassocioambientais/decisoes-recentes-ameacam-direitos-territoriais-indigenas-e-abrem-polemica-no-

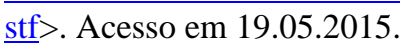


bastante violentas". ${ }^{141}$ Acreditam que assim estão evitando abrir discussões, que na verdade não constitui mera discussão, pois, o que está em jogo é defender ou não os direitos dos índios, qual seja, direitos sobre terras que foram tradicionalmente ocupadas anos antes da promulgação da Constituição de 1988, mas não reivindicadas segundo as regras da propriedade privada.

O grande equívoco, ou falso equívoco, é aplicar para as terras indígenas, terra de uso e não de troca, os princípios da propriedade privada, logo, uma total incoerência, inclusive com o requisito da tradicionalidade da ocupação da terra.

Além do requisito do marco temporal, o Supremo Tribunal Federal também requer para fins de reconhecimento de terra indígena a tradicionalidade da ocupação da terra (cf. art. 231, caput da CRFB). Esse entendimento é o compartilhado pela doutrina brasileira, como visto no tópico 2.1 deste trabalho. Deve-se verificar que a ocupação de uma área por índios esteja ocorrendo de modo tradicional, isto é, os índios estejam utilizando a terra para fins de exercício de suas tradições, costumes e bem estar, desempenhando atividades imprescindíveis para sua subsistência. Já que, de acordo com o Tribunal, as terras indígenas são demarcadas para que os índios tenham a garantia de que poderão viver de acordo com seus modos tradicionais, assim:

\footnotetext{
“Áreas indígenas são demarcadas para servir concretamente de habitação permanente dos índios de uma determinada etnia, de par com as terras utilizadas para suas atividades produtivas, mais as "imprescindíveis à preservação dos recursos ambientais necessários a seu bem-estar" e ainda aquelas que se revelarem "necessárias à reprodução física e cultural" de cada qual das comunidades étnico-indígenas, "segundo seus usos, costumes e tradições" (usos, costumes e tradições deles, indígenas, e não usos, costumes e tradições dos nãoíndios)."
}

\footnotetext{
${ }^{141}$ Voto do Ministro Gilmar Mendes no STF, Recurso Ordinário em Mandado de Segurança ${ }^{\circ}$ 29087 (DF), Brasília, 13 out 2014, p. 52.

${ }^{142}$ Plenário STF, Pet. 3.388 (RR), Rel. Ministro Carlos Ayres Britto, Brasília, 19 mar 2009.
} 
Esses dois requisitos foram verificados no caso da demarcação da terra indígena Raposa Serra do Sol, viabilizando que a homologação da terra indígena fosse confirmada pelo Supremo Tribunal Federal, pondo fim à todas controvérsias relativas a posse daquela terra.

\subsection{Caso Referência: Raposa Serra do Sol}

A terra indígena Raposa Serra do Sol (TIRSS) está localizada no nordeste do Estado de Roraima em região de fronteira brasileira com a Guiana e Venezuela. Diferentes povos indígenas como os Makuxi, Ingarikó, Wapixana, Taurepang e Patamona ocupam a TIRSS desde tempos imemoriais. ${ }^{143} \mathrm{O}$ estudo deste caso se faz fundamental no presente trabalho, pois o procedimento demarcatório da TIRSS ilustra os entraves administrativo, políticos e jurídicos ao reconhecimento da tradicionalidade das terras indígenas no estado brasileiro.

A terra indígena Raposa Serra do Sol hoje já demarcada, com homologação confirmada pelo Supremo Tribunal Federal, foi alvo de terrível disputa entre índios de diferentes etnias, rizicultores ${ }^{144} \mathrm{e}$ fazendeiros, desencadeando muitos casos de violência e morte na região. ${ }^{145}$ A disputa começou com o início da tentativa da Funai em demarcar a terra

\footnotetext{
${ }^{143}$ ROCHA, Ana Flávia Rocha (organização). A defesa dos direitos socioambientais no judiciário. Brasil: Instituto Socioambiental, 2003, p. 383.

144 "Somando-se a todas violações aos direitos humanos dos povos indígenas, desde 1996 um grupo de sete rizicultores foi instalado no interior da área indígena, com o apoio do governo estadual, propiciando crimes ambientais na região.” ROCHA, Ana Flávia Rocha (organização). A defesa dos direitos socioambientais no judiciário. Brasil: Instituto Socioambiental, 2003, p. 385.

${ }^{145}$ Como o caso do líder do grupo Makuxi, nesse sentido: "Em janeiro de 2003, o líder makuxi Aldo Mota foi assassinado dentro da fazenda do vereador Francisco Chagas. (...) O corpo foi enviado para o Instituto Médico Legal de Brasília que constatou que o índio makuxi foi executado com um tiro quando estava com os dois braços erguidos. O ministro da Justiça Márcio Thomaz bastos recebeu o laudo e imediatamente determinou à Policia Federal a intensificação das investigações e a total apuração do caso até a prisão dos criminosos.” ROCHA, Ana Flávia Rocha (organização). A defesa dos direitos socioambientais no judiciário. Brasil: Instituto Socioambiental, 2003, p. 385.
} 
indígena em 1977. ${ }^{146}$ Após diversas tentativas de se conduzir estudos antropológicos na TIRSS, qual muitas restaram infrutíferas ${ }^{147}$, o relatório só foi concluído em 1992 e entregue ao Ministério da Justiça. A área foi demarcada pelo Ministro da Justiça, através da Portaria n. ${ }^{\circ} 820^{148}$ apenas em 1998, declarando a existência de terra tradicionalmente ocupada por índios, os limites de sua extensão e a posse permanente dos índios Makuxi, Ingarikó, Wapixana, Taurepang e Patamona. A Portaria n. ${ }^{\circ}$ 820/1998 veio a ser modificada pela Portaria n. ${ }^{\circ}$ 534/2006, que aumentou a área de abrangência da demarcação e a TIRSS foi por fim homologada pelo Presidente da República através de Decreto sem número de 15 de abril de 2005.

O caso ganhou atenção nacional quando o Governo Federal iniciou a etapa de desocupação da terra por não índios (cf. previsto no art. $4^{\circ}$ do Decreto n. ${ }^{\circ}$ 1.775/96) e indenização das benfeitorias realizadas a partir da ocupação de boa-fé (cf. previsto no art. $231 \S 6^{\circ}$ da CRFB). Muitos fazendeiros e rizicultores, alguns com títulos de propriedade emitidos pelo governo do Estado de Roraima, recusaram-se a sair do local. Diante da reiterada negativa, foi necessário o envio por parte do Governo Federal, da Força Nacional, para auxiliar a Polícia Federal na remoção dos não índios e

\footnotetext{
${ }^{146}$ Conselho Indígena de Roraima. Raposa Serra do Sol: Os índios no futuro de Roraima. p. 32.

${ }^{147}$ ROCHA, Op. cit., p. 383.

${ }^{148}$ O governo de Roraima impetrou mandado de segurança n. ${ }^{\circ}$ 6210/1999 perante o Superior Tribunal de Justiça visando obter a declaração da nulidade da portaria. Alegando inconstitucionalidade do ato do Ministro da Justiça, por se tratar de área de fronteira, alegando que a demarcação indígena feria o direito de ir e vir de não indígenas dentro da região e que o ato era nulo por falta de motivação. $\mathrm{O}$ mandado de segurança foi extinto sem julgamento do mérito pelos ministros da $1^{a}$ seção do Superior Tribunal de Justiça, sob o fundamento que a matéria não poderia ser discutida sem dilação probatória, logo, não haveria direito líquido e certo a ser discutido em sede de mandado de segurança. Rocha, Op. cit., pp. 386-387.
}

O Senado Federal também tentou manobra política para suspender a demarcação, através da edição do Projeto de Decreto Legislativo n.o 106, proposto pelo senador Morazildo Calvalcante, "sob o argumento que o art. 49 da Constituição Federal legitima o Congresso Nacional para 'sustar os atos normativos do Poder Executivo que exorbitem o poder regulamentar ou dos limites de delegação legislativa, além da demarcação da Terra Indígena comprometer o progresso do Estado uma vez que existiria, segundo o senador, dentro da área 'inúneras fazendas produtivas estabelecidades há dezenas de anos'.” Rocha, Op. cit., p. 384 
possibilitar que o INCRA e a Funai realizassem a avaliação das benfeitorias existentes na terra para indenização. Diante desse quadro, o conflito desencadeou manifestações, prisões e assassinatos, tanto de índios, como de não índios.

Logo após a publicação do Decreto que homologou a demarcação da TIRSS, foi ajuizado perante o Supremo Tribunal Federal ação popular ${ }^{149}$ contra a União Federal, solicitando a nulidade da Portaria n. ${ }^{\circ}$ 534/2005 editada pelo Ministro da Justiça e do Decreto homologatório de 15 de abril de 2005. Os autores da demanda que defendiam os interesses dos latifundiários, alegaram vícios na edição das portarias que antecederam o Decreto, pois estas teriam violado o procedimento administrativo, sem que tivessem sido ouvidas as pessoas e entidades que seriam afetadas por sua edição. Além do mais, não se poderia admitir o modelo de demarcação contínua da terra indígena, pois este tipo de demarcação acarretaria problemas na economia do Estado de Roraima, uma vez que muitas fazendas de arroz, responsáveis pela geração de renda do Estado seriam fechadas e municípios desconstituídos. Alegaram também que o modelo de demarcação contínua também prejudicaria a defesa nacional, já que as terras indígenas estariam localizadas exatamente em área de fronteira. Razão pela qual o Estado de Roraima, que figurava como assistente dos autores, pleiteou a adoção da forma descontínua da demarcação, isto é, defendeu uma demarcação feita em blocos ou "ilhas" de terras para tentar evitar que algumas áreas fossem demarcadas. Desconsiderando portanto a tradição do uso da terra pelos indígenas.

Para agravar mais ainda a situação, não havia um entendimento comum entre os índios que viviam na TIRSS. Existia na época do conflito cerca de 20 mil índios, de diferentes etnias, cada uma com linguagem,

\footnotetext{
${ }^{149}$ Entendeu-se que o STF era o juízo competente para o processamento da demanda, assim "a competência originária desta Suprema Corte para o caso vertente foi reconhecida quando do julgamento da Reclamação 2.833. Ocasião em que ficou assentada a natureza federativa do conflito entre partes, de modo a deflagrar a incidência da alínea $f$ do inciso I do art. 102 da Constituição Federal”. Plenário STF, Pet. 3.388 (RR), Rel. Ministro Carlos Ayres Britto, Brasília, 19 mar 2009.
} 
costumes e tradições, defendendo interesses diversos. Alguns grupos indígenas defendiam a demarcação fracionada para possibilitar a permanência de alguns rizicultores nas terras tradicionalmente ocupadas, já outros grupos indígenas defendiam a demarcação continua, que não permitira a presença de não índios. ${ }^{150}$

A demanda caso referência sob relatoria do Ministro Carlos Ayres Britto buscou interpretar o art. 231 da Constituição Federal de 1988 e trouxe novos conceitos para palavras empregadas na norma constitucional. Diversas questões envolvendo os índios e terras foram enfrentadas.

Em primeiro lugar, entendeu-se que o art. 231 da CRFB ao reconhecer direito a posse permanente de terras tradicionalmente ocupadas, reconhece a todos os índios em geral, tanto a índios primitivos que se encontram mais isolados como a índios que vem sendo aculturados. Assim:

“O substantivo 'índios’ é usado pela Constituição Federal de 1988 por um modo invariavelmente plural, para exprimir a diferenciação dos aborígenes por numerosas etnias. (...) Índios em processo de aculturação permanecem índios para o fim de proteção constitucional. Proteção constitucional que não se limita aos silvícolas, estes, sim, índios ainda em primitivo estágio de habitantes da selva." ${ }^{151}$

Também reiterou-se o que Corte já vinha aplicando sobre o inciso XI do art. 20 da CRFB. No sentido de que as terras indígenas são um bem público da União Federal, sendo assim, parte integrante do território brasileiro. Logo, apesar de se haver um direito originário indígena sobre as terras que ocupam, anteriores a qualquer ato estatal, nenhuma terra tradicionalmente ocupada por índios se eleva a condição de uma unidade federada. Nesse sentido:

"Nenhuma terra indígena se eleva ao patamar de território político, assim como nenhuma etnia ou comunidade indígena se constitui em unidade federada. (...) A Constituição teve o cuidado de não falar em territórios indígenas, mas, tão-só, em 'terras indígenas'. A traduzir que os 'grupos', 'organizações', 'populações’ ou

\footnotetext{
150 Instituto Socioambiental. Terra Indígena Raposa Serra do Sol. Disponível em $<$ http://www.socioambiental.org/inst/esp/raposa $>$. Acesso em 20.05.2015.

${ }^{151}$ Plenário STF, Pet. 3.388 (RR), Rel. Ministro Carlos Ayres Britto, Brasília, 19 mar 2009.
} 
'comunidades' indígenas não constituem pessoas federada. Não formam circunscrição ou instância espacial que se orne de dimensão política.”152

Reafirmou-se a competência do Poder Executivo no procedimento de demarcação. Ao qual compete iniciar o procedimento através da Funai e a dar continuidade ao mesmo através da atuação do Ministro da Justiça e terminá-lo através de ato do Presidente da República, de acordo com o Decreto n. ${ }^{0}$ 1.775/1996. Caso as terras indígenas estejam em áreas de fronteira, como era o caso da TIRSS, pode o Presidente da República consultar o Conselho de Defesa Nacional. Assim:

\begin{abstract}
"Somente à União, por atos situados na esfera de atuação do Poder Executivo, compete instaurar, sequenciar e concluir formalmente o processo demarcatório das terras indígenas, tanto quanto efetivá-lo materialmente, nada impedindo que o Presidente da República venha a consultar o Conselho de Defesa Nacional”. ${ }^{153}$
\end{abstract}

Logo, por força do inciso III, § $1^{\circ}$ do art. 91 da CRFB, o Presidente da República pode consultar o Conselho de Defesa Nacional no procedimento demarcatório, porém não se trata de uma obrigação que culminaria com a nulidade de procedimento demarcatório. De acordo com o inciso III, $\S 1^{\circ}$ do art. 91 da CRFB, compete ao Conselho de Defesa Nacional "propor os critérios e condições de utilização de áreas indispensáveis à segurança do território nacional e opinar sobre seu efetivo uso, especialmente na faixa de fronteira e nas relacionadas com a preservação e a exploração dos recursos naturais de qualquer tipo”, ficando facultado ao Presidente da República nos procedimentos de demarcação consultar o órgão. Ficou decidido pelo Tribunal que a presença de índios e aldeias em região de fronteira não constitui um entrave à defesa nacional. Muito pelo contrário, entendeu-se que índios podem ajudar a evitar a presença de pessoas estranhas ao território brasileiro e ajudam a promover a presença estatal na região. Conforme observou o Ministro Carlos Ayres Britto:

\footnotetext{
${ }^{152}$ Plenário STF, Pet. 3.388 (RR), Rel. Ministro Carlos Ayres Britto, Brasília, 19 mar 2009.

${ }^{153}$ Ibid.
} 
"Há compatibilidade entre o usufruto de terras indígenas e faixa de fronteira. Longe de se pôr como um ponto de fragilidade estrutural das faixas de fronteiras, a permanente alocação indígena nesses estratégicos espaços em muito facilita e até obriga que as instituições de Estado (Forças Armadas e Polícia Federal, principalmente) se façam também presentes com seus postos de vigilância $(\ldots)^{, 154}$

Ficou assentado que o artigo 231 da Constituição Federal, que consagra a causa indígena seria, nas palavras do Ministro Carlos Ayres Britto, um “capítulo avançado do constitucionalismo fraternal (...) de

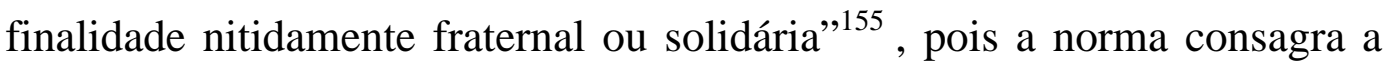
efetivação da igualdade de minorias, a integração comunitária e a preservação e reconhecimento das tradições dos povos indígenas. Nesse sentido a norma viabilizaria a compensação das perdas que os índios sofreram no passado, permitindo que hoje possam “desfrutar de um espaço fundiário que lhes assegure meios dignos de subsistência econômica para mais eficazmente poderem preservar sua identidade somática, linguistica e cultural"156.

Contudo, apesar de se tratar de uma norma que visa garantir a compensação das perdas que os índios sofreram no passado houve a aplicação da teoria do marco temporal no caso. Apesar dos índios da TIRSS terem obtido êxito na demanda, conseguindo obter a declaração da validade da demarcação de suas terras e consequentemente a retirada de não índios do local, o marco temporal desde então passou a ser aplicado em muitos julgamentos posteriores que usam como referência o caso da TIRSS. Infelizmente, nem todas as populações tradicionais poderão ter suas terras demarcadas por conta da interpretação deste requisito, pois, se não estavam ocupando as terras em 5 de outubro de 1988, segundo esse entendimento do STF, não terão direito a posse permanente e nem ao usufruto exclusivo. Nascendo então um novo desafio, do qual ainda não se sabe as conseqüências.

\footnotetext{
154 Ibid.

155 Ibid.

156 Ibid.
} 


\section{CAPÍTULO 4. CONCLUSÃO}

A pesquisa realizada considerou a situação de vulnerabilidade do povo indígena no Brasil desde a época da colonização portuguesa, agravada nos processos de demarcação de terras com a reduzida eficácia social da norma constitucional, fundada no indigenato, que protege os direitos indígenas.

Para tratar do direito originário dos povos indígenas sobre as terras que tradicionalmente ocupam foi fundamental abordar o processo de colonização das terras brasileiras pelos portugueses, onde o reconhecimento do direito originário sobre as terras remonta ao passado histórico.

Constatou-se que com a chegada do colonizador português os índios foram destituídos de suas terras. Aqueles que não resistiram à colonização foram alocados em aldeamentos controlados por jesuítas, enquanto que o restante fugiu para terras interioranas ou foram eliminados.

A nova forma territorial de viver imposta pelo colonizador desrespeitou a tradição indígena, impedindo que os índios vivessem segundo os costumes passados por seus ancestrais. A terra era um elemento sagrado e de subsistência, enquanto que para o colonizador o interesse estava restrito à exploração econômica.

Na linha do tempo a história das terras indígenas reuniu momentos normativos bastante diversos. As Cartas Régia de 30 de julho de 1609 e de 10 de setembro de 1611 reconheceram o pleno dominio dos índios sobre suas terra e o Regimento das Missões do Estado do Maranhão e Pará de 1668 manteve a regra. O Alvará Régio de 1680 e a Lei de 06 de junho de 1755 reconheceram também serem os índios os "primários e naturais senhores" de suas terras abrindo o espaço para o regime do indigenato. Em 1718 a Carta Régia de 9 de março declarou que os índios eram livres e isentos da jurisdição portuguesa. Posteriormente em 1819 a legislação determina que as terras indígenas seriam inalienáveis, sendo nulas as concessões de sesmarias eventualmente feitas nas terras indígenas. 
No período imperial, ao contrário, no Brasil houve um retrocesso nos direitos indígenas sobre a terra. Os índios deixaram de ser considerados brasileiros.

Embora desde os tempos coloniais diversas legislações tenham reconhecido o direito a posse das terras originárias aos índios, na prática o exercício desse direito nunca pode ser plenamente exercido, pois sempre esteve presente a prática do esbulho, seja pelos colonizadores, seja pelos que vieram depois.

A falta da terra não consiste apenas ausência da propriedade material. Como visto ao longo do trabalho, para muitos indígenas, deixar de reconhecer o direito à terra implica na diminuição de populações, a assimilação e perda da sua identidade cultural e tradicional, que está intimamente ligada ao terreno habitado por suas famílias durante gerações.

O grande divisor de águas, sem duvida, foi a Constituição de 1988. É inegável o avanço que houve na luta indígena com a promulgação da Constituição da República Federativa do Brasil de 1988.

O artigo 231 da Constituição Federal de 1988 consagra o instituto do indigenato, que se funda na existência de um direito originário indígena sobre as terras que tradicionalmente ocupadas. Assim é assegurado o direito a posse permanente e ao usufruto exclusivo das terras pelos indígenas.

Para garantia da posse indígena é necessária que seja procedida a demarcação dessas terras pelo Poder Executivo, evidenciando os limites territoriais e barrando a invasão das áreas indígenas.

Com efeito, para que os índios usufruam plenamente do direito da posse permanente as terras que tradicionalmente ocupam e garantam sua existência de acordo com seus usos, costumes e tradições é fundamental que a norma do art. 231 da CRFB alcance a máxima efetividade, sendo conseqüentemente, eficaz, tornando, através da eficácia social da norma a necessária aplicabilidade da norma jurídica, garantindo com a correspondência entre a realidade e o conteúdo da norma, as tradições e identidade cultural indígena. 
Desde a colonização até os dias hoje os índios tiveram suas terras esbulhadas por interesses de ordem econômica e continuam sendo encarados por muitos como verdadeiro obstáculo à posse da terra. No início o esbulho se deu por conta do cultivo da cana de açúcar e, após vários séculos, se dá devido a atividades agropecuárias, extrativistas e minerais. Pode-se dizer que o passado se repete nos dias de hoje, isto porque o esbulho nunca deixou de ocorrer. Ou seja, trata-se de uma violação continua aos direitos originários indígenas sobre a terra, que vem ocorrendo até os dias de hoje, mas perpetrados por diferentes agentes, mesmo sempre havendo proteção legal às terras tradicionalmente ocupadas.

A pesquisa demonstrou que o esbulho às terras indígenas é ora de ordem pública, ora privada. É pública quando o próprio governo, incumbido de fazer valer o ordenamento jurídico, obstrui o procedimento administrativo demarcatório previsto na Lei Federal n. ${ }^{\circ}$ 6.001/1973, regulamentada pelo Decreto n. ${ }^{0}$ 1.775/1996, seja ignorando os prazos previstos nas etapas de demarcação, seja deixando de definir a demarcação através de portaria (dever do Ministro da Justiça) ou deixando de editar decreto homologando a terra tradicionalmente ocupada (dever do Presidente da República).

O estudo também alcançou diversas propostas de emenda à Constituição no Congresso Nacional, que visam mitigar os direitos originários dos índios sobre as terras ocupadas e transferir a competência demarcatória do Poder Executivo para o Poder Legislativo, afrouxando ainda mais um procedimento demarcatório que na prática já não tem se mostrado tão eficaz.

A proposta mais preocupante é a trazida pela PEC n. ${ }^{\circ} 215$. Ela visa acrescentar o inciso XVIII ao art. 49, modificar o $\S 4^{\circ}$ do art. 231 e acrescentar o $\S 8^{\circ}$ ao art. 231 da Constituição Federal, dispondo que é de competência exclusiva do Congresso Nacional a aprovação de demarcação das terras tradicionalmente ocupadas pelos índios e a ratificação das demarcações já homologadas pelo Presidente da República. 
Embora a justificativa da proposta de emenda constitucional seja no sentido de evitar conflitos federativos e proporcionar maior segurança jurídica às demarcações, o mais provável é que a proposta vise pura e simplesmente, mitigar a posse permanente do índio à terra, facilitando assim a posse dessa mesma terra por setores da economia interessados em sua exploração.

O papel de demarcar, proteger e fazer respeitar todos os bens indígenas não vem sendo cumprido adequadamente por omissão, tanto do Poder Executivo, quanto do Poder Legislativo. Do primeiro quando deixa de proceder com a demarcação e/ou não dá amparo policial nas áreas tradicionalmente ocupadas que são alvos do agronegócio e de outras atividades econômicas, já do segundo, quando edita projetos de lei e de emenda constitucional tendentes a abolir o direito originário dos índios sobre as terras que tradicionalmente ocupam. Grande parte dos membros do Congresso Nacional vem defendendo, única e exclusivamente, os interesses e anseios econômicos dos latifundiários.

É de se espantar que o direito originário dos índios sobre as terras que tradicionalmente ocupam, reconhecido desde 1680, ainda não foi consolidado na prática até hoje. A manutenção da posse permanente da terra pelos índios é precária, haja vista que não detém o poder financeiro e tampouco de proteção frente aos invasores, que se fazem valer através do uso da força e violência quando os índios se recusam a sair das terras espontaneamente. A disputa pela posse da terra vem por muitos anos acarretando mortes no Brasil.

Diante deste conflituoso quadro nacional, o Poder Judiciário é freqüentemente acionado, tanto por índios como por não índios. De um lado, representados pela Funai e organizações não governamentais, os índios tendem a solicitar a tutela necessária para proteger suas terras e integridade física frente a invasores e à omissão pública no procedimento de demarcação. Por sua vez os não índios visam conseguir decisão judicial que declare a posse e propriedade da terra como suas, tornando ilegítima a 
permanência dos índios nas terras que tradicionalmente habitam ou que anule ou suspenda o procedimento administrativo de demarcação. Desse modo, a Justiça Federal é freqüentemente acionada para dirimir disputas possessórias e controvérsias sobre o procedimento administrativo da demarcação, culminando com a demarcação judicial.

Apesar de ser uma corte de acesso limitado, muitas demandas logram a chegar no Supremo Tribunal Federal, que vem aplicando o art. 231 da Constituição Federal, e assim reconhece a importância de se garantir a posse permanente da terra aos índios, para que possam viver de acordo com os seus usos, costumes e tradições.

Se por um lado o entendimento do STF vem sendo favorável aos índios, por outro, a criação do requisito do marco temporal, presente no caso da demarcação da Terra Indígena Raposa Serra do Sol, é um obstáculo para se garantir a posse permanente de terras por comunidades indígenas que não habitavam suas terras em 5 de outubro de 1988. A utilização desse critério inviabilizará que seja feita justiça à todas as comunidades indígenas, eis que muitas delas não ocupavam suas terras nessa data estipulada pelo STF.

Judicializar o procedimento administrativo demarcatório implica no aumento de sua morosidade, acarretando no atraso da demarcação, pois não índios muitas vezes conseguem medidas liminares que suspendem o procedimento administrativo até a decisão final de mérito.

Se por um lado o procedimento fica mais lento, o STF, muitas vezes confirmou a homologação das terras, viabilizando a posse permanente dos índios, pondo fim a conflitos possessório que se estenderam por décadas, como o caso da Raposa Serra do Sol, iniciado na década de 70 e terminado em 2009.

Vitórias como esta, no entanto são parciais, pois a fixação de uma data específica de ocupação da terra por muitas vezes restringe os direitos dos povos indígenas a posse efetiva de suas terras. As exceções ao marco 
temporal são muito restritas e discriminatórias e agravam ainda pela histórica vulnerabilidade dos índios. 


\section{Referências Bibliográficas}

AMADO, Luiz Henrique Eloy; TENÓRIO, Lilian Raquel Ricci. A luta do povo Terena por seus territórios tradicionais: Reflexões sobre demarcação, judicialização e mesa de diálogo. Disponível em $<$ http://www.seminarioamericaplatina.com/restrito/trabalho/Luiz-HenriqueEloy-Amado-301014-2335artigo_eloy\%20e\%20lilian_versao\%20final.pdf>. Acesso em 28.05.2015.

Guarani e Kaiowá na luta pela terra: Levantamento preliminar da situação jurídica. Disponível em <http://www.seminarioamericaplatina.com/restrito/trabalho/L\%C3\%ADlian -Raquel-Ricci-Ten\%C3\%B3rio-301014-2359artigo_lilian\%20e\%20eloy\%20versao\%20final.pdf $>$. Acesso em 28.05.2015.

BARROSO, Luís Roberto. Direito Constitucional e a efetividade de suas normas. Rio de Janeiro: Editora Renovar, 2009.

BUARQUE DE HOLANDA, Sérgio (direção). História Geral da Civilização Brasileira: A Época Colonial. $3^{\mathrm{a}}$ ed. São Paulo: Difusão Européia do Livro, 1968.

CARNEIRO DA CUNHA, Manuela (organização). História dos índios brasileiros. São Paulo: Companhia das Letras e Secretaria Municipal de Cultura, 1992.

Os direitos do índio ensaios e

documentos. São Paulo: Ed. Brasiliense S.A., 1987.

Comissão Pró-Índio de São Paulo. Cenaìrio nacional eì de paralisaçaDo das demarcaçoDes de terras indiìgenas. Disponível em $<$ http://www.cpisp.org.br/indios/upload/editor/files/MateriaOcenariodeparal isacao.pdf >. Acesso em 11.05.2015.

COLACO, Thais Luzia. Incapacidade indígena: Tutela religiosa e violação do direito guarani nas missões Jesuíticas. $1^{\text {a }}$ ed. Curitiba: Juruá, 2003.

Legislação indígena: os índios e a lei - história e contemporaneidade. In: XII Simpósio Internacional IUH: A experiência missioneira: território, cultura e identidade. São Leopoldo: Casa Leiria, 2010. 
FERRAZ JUNIOR, Tercio Sampaio. Introdução ao estudo do direito: Técnica, decisão, dominação. 6a ed. São Paulo: Editora Atlas, 2008.

FOUCAULT, Michel. Vigiar e Punir: Nascimento da Prisão. 29a ed. [traduzido por] Raquel Ramalhete. Petrópolis: Editora Vozes, 2004.

FONTENELE, Cristina. Governo federal é refém do agronegócio e antiindígena, denuncia bispo do Xingu. Disponível em $<\underline{\text { http://www.cimi.org.br/site/pt- }}$

br/?system=news\&conteudo_id=8103\&action=read $>$, acesso em 07.05.2015.

FUNAI. Entenda o processo de demarcação. Disponível em $<$ http://www.funai.gov.br/index.php/2014-02-07-13-24-53> acesso em 17.04.2015.

Por que demarcar?. Disponível em

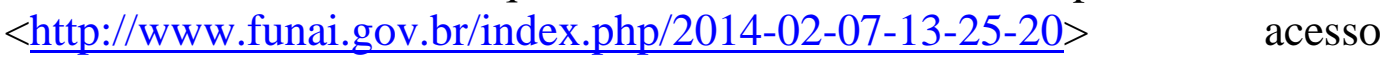
18.04.2015.

Terras Indígenas. Disponível em <http://www.funai.gov.br/index.php/indios-no-brasil/terras-indigenas $>$. Acesso em 19.05.2015.

GARATTONI, Bruno. A terra sagrada dos índios. Disponível em <http://super.abril.com.br/cotidiano/terra-sagrada-indios-752921.shtml>. Acesso em 20.03.2015.

GARCIA, Pedro. O movimento indígena e a demarcação das terras. Brasília: Funai, 2002.

GARFIELD, Seth. Luta indígena no coração do Brasil. Brasil: Editora Unesp, 2011.

FURUIE, Vinicius. Índios encontram dificuldade em demarcar terras. Disponível em $\quad<$ http://www.conjur.com.br/2007-mai20/indios encontram dificuldade demarcar_terra $>$. Acesso em 11.05.2015.

HOBSBAWM, Eric; RANGER, Terence. A invenção das tradições. $6^{\mathrm{a}}$ Ed. Rio de Janeiro: Paz e Terra, 2008.

Instituto Socioambiental. Após mobilização indígena, Dilma homologa três Terras Indígenas e autoriza contratação para Funai. Disponível em <http://www.socioambiental.org/pt-br/noticias-socioambientais/aposmobilizacao-indigena-dilma-homologa-tres-terras-indigenas-e-autorizacontratacao-para-funai>, acesso em 07.05.2015. 
Instituto Socioambiental. Terra Indígena Raposa Serra do Sol. Disponível em $<$ http://www.socioambiental.org/inst/esp/raposa $>$. Acesso em 20.05.2015.

LEITÃO, Raimundo Sérgio Barros. Natureza jurídica do ato administrativo de reconhecimento de terra indígena - a declaração em juízo, In: SANTILLI, Juliana (Coord.), Os Direitos Indígenas e a Constituição. Porto Alegre: Sergio Antonio Fabris Editor, 1991.

LIMA, Manoel S. de. Demarcação de terras: impactos e desafios na construção da cidadania dos povos indígenas. In GRAMKOW, Márcia Maria (organizado). Demarcando terras indígenas II. Brasilia: Funai, 2002

LOPES, Nei. História e cultura dos povos indígenas no Brasil. São Paulo: Barsa Planeta, 2009.

MENDES JÚNIOR, João. Os indígenas no Brazil: Seus direitos individuaes e políticos. São Paulo: Typ. Hennies Irmãos, 1912.

Ministério da Justiça. Ministro considera inconstitucional PEC da demarcação de terras indígenas. Disponível em $<$ http://www.justica.gov.br/noticias/ministro-considera-inconstitucionalpec-da-demarcacao-de-terras-indigenas $>$, acesso em 11.05.2015.

NADER, Paulo. Introdução ao estudo do direito. $32^{\mathrm{a}}$ ed. Rio de Janeiro: Forense, 2010.

RIBEIRO, Darcy. Os índios e a civilização. $2^{\mathrm{a}}$ ed. Petrópolis: Vozes Ltda, 1977.

A política indigenista brasileira. $1^{\text {a }}$ ed. Rio de Janeiro: Ministério da Agricultura, 1962.

ROCHA, Ana Flávia Rocha (organização). A defesa dos direitos socioambientais no judiciário. Brasil: Instituto Socioambiental, 2003.

SANTILI, Juliana (organização). Os direitos indígenas e a constituição. Porto Alegre: Núcleo de Direitos Indígenas, 1993.

SARMENTO, Daniel. Nota Técnica: A PEC 215/00 e as Cláusulas Pétreas. Disponível em $<$ http://noticias.pgr.mpf.mp.br/noticias/noticias-dosite/copy_of_indios-e-minorias/portal_factory/copy_of_pdfs/nota-pec-215final-1-1.pdf $>$. Acesso em 05.04.2015. 
SILVA, Jose Afonso da. Curso de Direito Constitucional Positivo. $37^{\mathrm{a}}$ ed. Brasil: Malheiros, 2014.

Souza, Oswaldo Braga de. Decisões recentes ameaçam direitos territoriais indígenas e abrem polêmica no STF. Disponível em $<$ http://www.socioambiental.org/pt-br/noticias-socioambientais/decisoesrecentes-ameacam-direitos-territoriais-indigenas-e-abrem-polemica-no-stf $>$. Acesso em 19.05.2015.

TOURINHO NETO, Fernando da Costa. Os direitos originários dos índios sobre as terras que ocupam e suas conseqüencias jurídicas. In Os Direitos Indígenas e a Constituição. Ed. Núcleo de Direitos Indígenas. Porto Alegre, 1993.

VALENTE, Rubens. Senadores assinam documento contra PEC que muda demarcação de terras. Folha de São Paulo, Brasília, 27.05.2015, disponível em <http://www1.folha.uol.com.br/poder/2015/05/1634401-senadoresassinam-documento-contra-pec-que-muda-demarcacao-de-terras.shtml $>$. Acesso em 28.05.2015.

VICENTINO, Cláudio; DORIGO, Gianpaolo. História do Brasil. $1^{\text {a }}$ ed. São Paulo: Scipione, 2004 